Rutile in Precambrian

Sillimanite-Quartz Gneiss

and Related Rocks,

East-Central Front Range,

Colorado

GEOLOGICAL SURVEY PROFESSIONAL PAPER 959-G
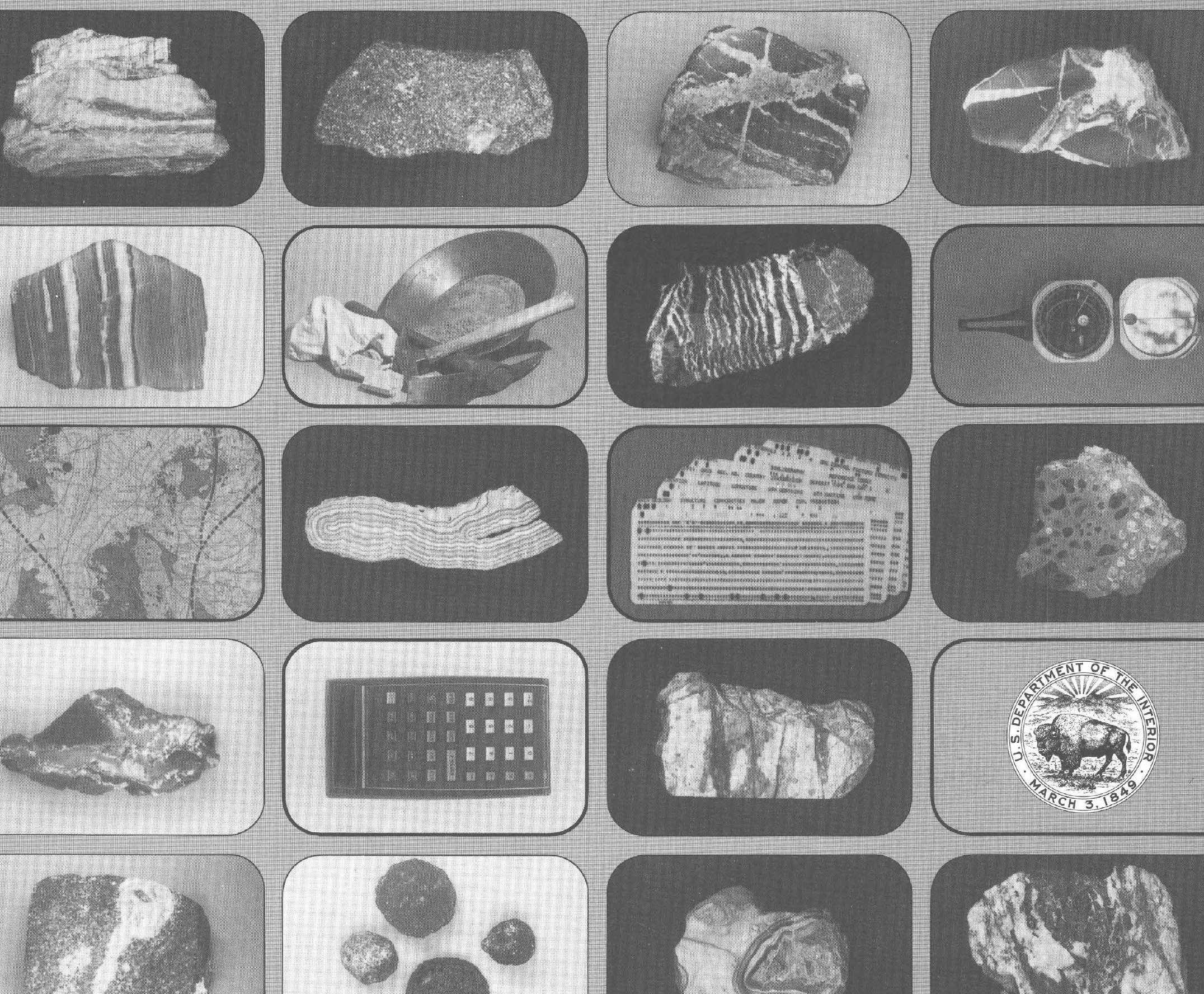
COVER PHOTOGRAPHS

\begin{tabular}{|c|c|c|c|c|}
\hline 1 & 2 & & & 1. Asbestos ore \\
\hline 1 & 2 & 3 & 4 & 2. Lead ore, Balmat mine, N. Y. \\
\hline \multirow[t]{2}{*}{5} & & 6 & & 3. Chromite-chromium ore, Washington \\
\hline & 7 & & 8 & 5. Banded iron-formation, Palmer, \\
\hline 9 & & 10 & & $\begin{array}{l}\text { Mich. } \\
\text { 6. Ribbon asbestos ore, Quebec, Canada }\end{array}$ \\
\hline 11 & 12 & 13 & 14 & $\begin{array}{l}\text { 7. Manganese ore, banded } \\
\text { rhodochrosite }\end{array}$ \\
\hline
\end{tabular}

8. Aluminum ore, bauxite, Georgia

9. Native copper ore, Keweenawan Peninsula, Mich.

10. Porphyry molybdenum ore, Colorado

11. Zinc ore, Edwards, N. Y.

12. Manganese nodules, ocean floor

13. Botryoidal fluorite ore, Poncha Springs, Colo.

14. Tungsten ore, North Carolina 


\section{Rutile in Precambrian Sillimanite-Quartz Gneiss and Related Rocks, East-Central Front Range, Colorado}

By SHERMAN P. MARSH and DOUGLAS M. SHERIDAN

GEOLOGY AND RESOURCES OF TITANIUM IN THE UNITED STATES

GEOLOGICAL SURVEY PROFESSIONAL PAPER 959-G

Geologic and geochemical study of rutile-bearing rocks in Colorado and a description of their occurrence elsewhere

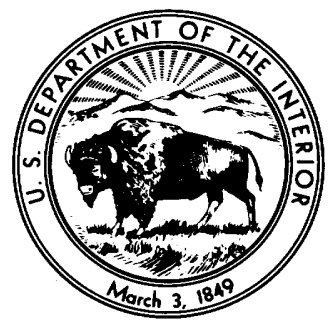




\section{UNITED STATES DEPARTMENT OF THE INTERIOR}

THOMAS S. KLEPPE, Secretary

GEOLOGICAL SURVEY

V. E. McKelvey, Director

Library of Congress Cataloging in Publication Data

Main entry under title:

Geology and resources of titanium in the United States.

(Geological Survey Professional Paper 959)

CONTENTS: Force, E. R. Titanium contents and titanium partitioning in rocks.-Force, E. R. Metamorphic source rocks of titanium placer deposits.-Black, M. C., Jr. and Morgan, B. A. Rutile and sphene in blueschist and related high-pressure facies rocks.-Herz, N. Titanium deposits in anorthosite massifs.-Herz, N. Titanium deposits in alkalic igneous rocks. - Force, E. R. Titanium minerals in deposits of other minerals.-Marsh, S. P. and Sheridan, D. M. Rutile in precambrian sillimanite-quartz gneiss and related rocks, east-central Front Range, Colorado.

Includes bibliographies.

Supt. of Docs. no.: I 19.16:959 A-G

1. Titanium ores-United States. 2. Petrology-United States.

I. Series: United States Geological Survey Professional Paper 959.

QE390.2.T5G46 553'.462 75-619269

For sale by the Superintendent of Documents, U.S. Government Printing Office

Washington, D.C. 20402

Stock Number 024-001-02834-4 


\section{APPRAISAL OF MINERAL RESOURCES}

Continuing appraisal of the mineral resources of the United States is conducted by the U.S. Geological Survey in accordance with the provisions of the Mining and Minerals Policy Act of 1970 (Public Law 91-631, Dec. 31, 1970). Total resources for purposes of these appraisal estimates include currently minable resources (reserves) as well as those resources not yet discovered or not currently profitable to mine.

The mining of mineral deposits, once discovered, depends on geologic, economic, and technologic factors; however, identification of many deposits yet to be discovered, owing to incomplete knowledge of their distribution in the Earth's crust, depends greatly on geologic availability and man's ingenuity. Consequently, appraisal of mineral resources results in approximations, subject to constant change as known deposits are depleted, new deposits are found, new extractive technology and uses are developed, and new geologic knowledge and theories indicate new areas favorable for exploration.

This Professional Paper discusses aspects of the geology of titanium as a framework for appraising resources of this commodity in the light of today's technology, economics, and geologic knowledge.

Other Geological Survey publications relating to the appraisal of resources of specific mineral commodities include the following:

Professional Paper 820-“United States Mineral Resources"

Professional Paper 907-"Geology and Resources of Copper Deposits"

Professional Paper 926-"Geology and Resources of Vanadium Deposits"

Professional Paper 933-"Geology and Resources of Fluorine in the United States" 



\section{CONTENTS}

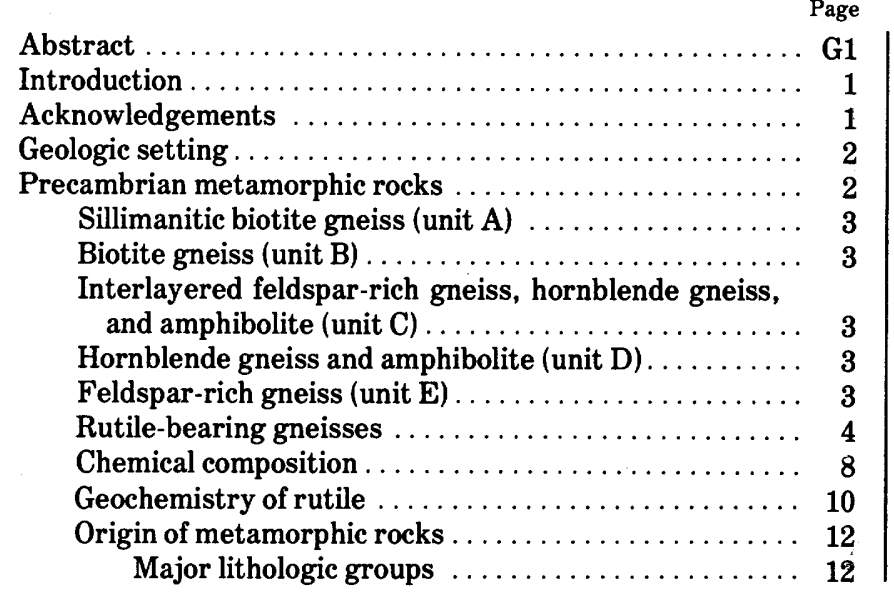

Precambrian metamorphic rocks-Continued

Origin of metamorphic rocks-Continued Rutile-bearing gneisses.

Other localities of rock types similar to those in the east-central Front Range ..................... 13

Farmville district, Virginia ................ 14

Kings Mountain district, North Carolina-

South Carolina ......................... 14

Graves Mountain, Georgia ................. 14

White Mountain, California . . . . . . . . . . . . . . 14

Yuma County, Arizona ................... 15

Santa Cruz County, Arizona .................... $\quad 15$

Other United States occurrences . . . . . . . . . . . 15

World occurrences ....................... 15

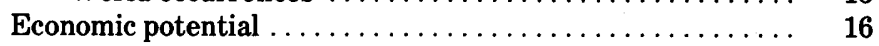

References cited $\ldots \ldots \ldots \ldots \ldots \ldots \ldots \ldots \ldots \ldots \ldots \ldots, 17$

\section{ILLUSTRATIONS}

FigURE 1. Map showing distribution of Precambrian igneous and metamorphic rocks in east-central Front Range, Colo. .........

2. Generalized geologic map showing distribution of Precambrian rutile-bearing gneiss, east-central Front Range ........

3-8. Photomicrographs:

3. Rutile alined parallel to foliation in biotite-quartz-plagioclase gneiss $\ldots \ldots \ldots \ldots \ldots \ldots \ldots \ldots \ldots \ldots \ldots$

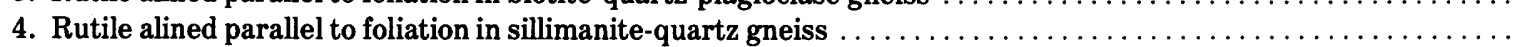

5. Fibrolitic sillimanite partly replaced by topaz and partly recrystallized to prismatic sillimanite $\ldots \ldots \ldots \ldots \ldots$

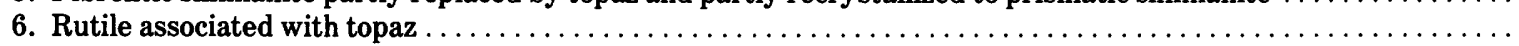

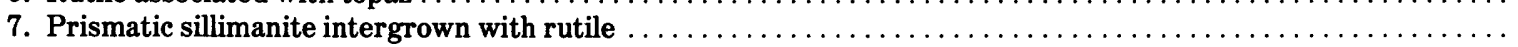

8. Rutile associated with corundum.

\section{TABLES}

T ABLE 1. Analytical data for rutile-bearing gneiss and for other Precambrian metamorphic rocks, east-central Front Range, Colo.

2. Semiquantitative spectrographic analyses of rutile

3. Standard of purity for rutile.

4. Ionic substitution factors

\section{METRIC-ENGLISH EQUIVALENTS}

\begin{tabular}{lcc}
\hline \multicolumn{1}{c}{ Metric unit } & & English equivalent \\
\hline centimetre $(\mathrm{cm})$ & $=0.3937$ & inch (in) \\
metre $(\mathrm{m})$ & $=3.28$ & feet $(\mathrm{ft})$ \\
kilometre $(\mathrm{km})$ & $=.62$ & mile (mi) \\
\hline
\end{tabular}





\title{
RUTILE IN PRECAMBRIAN SILLIMANITE-QUARTZ GNEISS AND RELATED ROCKS, EAST-CENTRAL FRONT RANGE, COLORADO
}

\author{
By Sherman P. MARSh and Douglas M. SHERIDAN
}

\begin{abstract}
Unusual rutile-bearing gneisses are thinly interlayered with metasedimentary and metavolcanic gneisses of Precambrian age in the east-central part of Colorado's Front Range. Layers and lenses of rutile-bearing gneiss range in thickness from $15 \mathrm{~cm}$ to $30 \mathrm{~m}$ and in rutile content from trace amounts to about 5 percent. Rutile is most abundant in a sillimanitic topaz-quartz gneiss but is also found in sillimanite-quartz gneiss and biotite-quartz-plagioclase gneiss. The rutile-bearing sillimanitic gneisses have a simple but unusual mineral and chemical composition because they contain little else but quartz, sillimanite, \pm topaz, and accessory rutile. Spectrographic analyses of rutile from the east-central Front Range and from eleven other localities in the United States indicate that the Front Range rutile is relatively pure, that is, it contains fewer metallic cations.

We believe that the rutile-bearing gneisses originated from intermediate to basic tuffs and flows; intense weathering resulted in clays enriched in titania, alumina, and silica. These weathering products were reworked by surface waters, and fluorine from volcanic sources was adsorbed locally. Subsequently, the entire sequence of interlayered sedimentary and volcanic rocks was folded and metamorphosed to the sillimanite zone by regional metamorphism.

Although the majority of known occurrences of rutile-bearing gneiss in the east-central Front Range may never be mined, owing to environmental and economic factors, this type of rutile occurrence is also found elsewhere and may represent potential rutile resources.
\end{abstract}

\section{INTRODUCTION}

Rutile occurs in thin layers and lenses of light-colored sillimanite-quartz gneiss and related rocks within a thick succession of Precambrian metamorphic rocks in the east-central Front Range, Colo. The known occurrences are in a belt, $3 \mathrm{~km}$ wide and $26 \mathrm{~km}$ long, that extends east-southeast from the vicinity of Idaho Springs to $4 \mathrm{~km}$ south of Morrison (figs. 1, 2). Layers and lenses of rutile-bearing gneiss range in thickness from $15 \mathrm{~cm}$ to $30 \mathrm{~m}$ and in rutile content from trace amounts to 5 percent.
The presence of rutile in an unusual sillimanitic topaz-quartz gneiss located $10 \mathrm{~km}$ northwest of Evergreen, Colo., was noted in March 1968 by D.M. Sheridan during petrographic studies related to a program of regional mapping. D. M. Sheridan, S. P. Marsh, and R. B. Taylor reported the results of a preliminary geologic investigation of this deposit in U.S. Geological Survey Circular 567 (Sheridan, Taylor and Marsh, 1968). Marsh and Sheridan continued searching for additional deposits of rutile during field studies in 1968-69. Because the rutile-bearing rocks described here are rather undistinguished in appearance, they might very easily be overlooked, even by a trained geologist.

This report summarizes the results of field and laboratory examinations of rutile-bearing gneisses of the east-central Front Range. These gneisses constitute a large resource of rutile. Rocks such as the sillimanitic topaz-quartz gneiss could be mined principally for topaz and sillimanite, both of which can be used by high-alumina refractory industries for the manufacture of mullite; salable byproducts of such an operation would be rutile, crushed quartz, and fluorine. The fact that these gneisses have not as yet been mined may be attributed to the high cost of hard-rock mining and milling (compared to the low-cost methods used in obtaining rutile from Australian beach sands); rising land values due to the westward spreading of suburban Denver; and likely objections of local residents. Although the rutile deposits described in this report may never be mined, similar deposits may be found in other gneissic terranes where mining might be possible.

\section{ACKNOWLEDGMENTS}

A major part of this investigation was conducted under a comprehensive research program authorized 

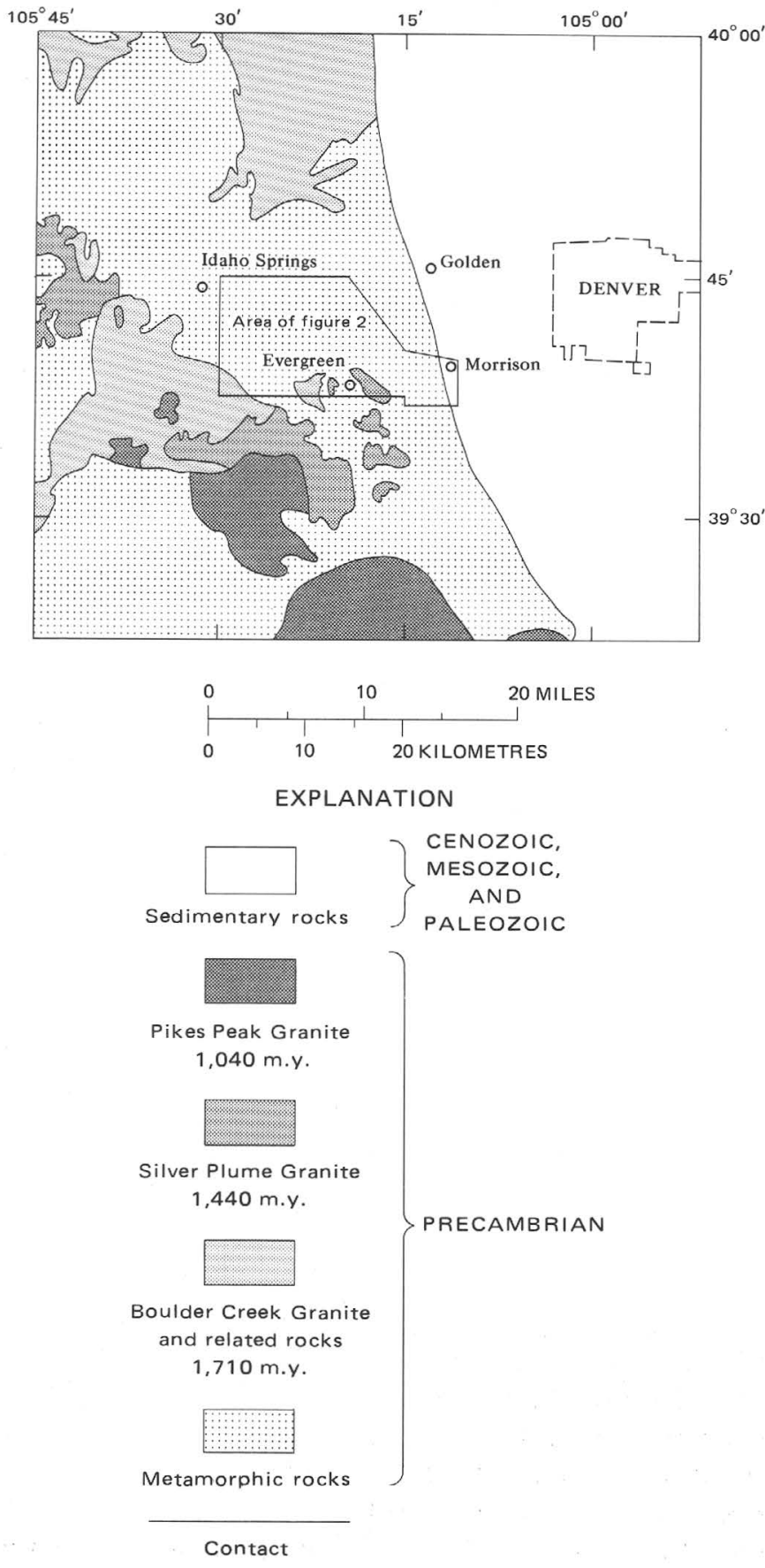

Figure 1.-Distribution of Precambrian igneous and metamorphic rocks in the east-central Front Range, Colo. (faults and Tertiary igneous rocks omitted).

by the Office of Emergency Planning and undertaken by the Department of the Interior under the Defense Production Act for the purpose of developing a domestic source of rutile. U. S. Geological Survey colleagues W. N. Sharp, J. W. Adams, R. B. Taylor, Mary E. Mrose, and R. L. Erickson have helped with mineralogy and report preparation.

\section{GEOLOGIC SETTING}

The rutile-bearing gneisses lie within a broad area of Precambrian metamorphic and intrusive rocks in the east-central Front Range (fig. 1). Metamorphic rocks in this part of the Front Range are principally biotite gneisses and feldspathic gneisses, but amphibolite, hornblende gneiss, and calc-silicate gneiss are abundant in the east. All the area shown in figure 1 is in the sillimanite zone of regional metamorphism. Most of the pelitic rocks of the report area (fig. 2) are characterized by the stable pair sillimanite and potassic feldspar, but rocks of somewhat lower grade, characterized by the pair sillimanite/muscovite are common in areas to the northeast (Sheridan, Maxwell, and Albee, 1967, p. 37-38) and southeast (Bryant and others, 1973, p. 3.) In the east-central Front Range this high-grade metamorphism accompanied a long period of deformation involving two stages of plastic folding, the first of which formed tight to open folds trending west to northwest; these trends predominate in the report area (fig. 2). Elsewhere, these folds were modified subsequently by cross folds trending north-northwest to north-northeast (R. B. Taylor, oral commun., 1964). Late in this long period of tectonism, bodies of Boulder Creek Granite (largely granodiorite) were intruded; isotopic dating by $\mathrm{Rb} / \mathrm{Sr}$ determinations indicates that the Boulder Creek Granite is about $1,710 \pm 40$ m.y. old (Hedge, 1969, p. 79). A third episode of folding, also accompanied by regional metamorphism and followed closely be cataclastic deformation, affected parts of the east-central Front Range at about the time the Silver Plume Granite was emplaced (R. B. Taylor, oral commun., 1967; Moench and others, 1962, p. 45-54; Sheridan, Maxwell, and Albee, 1967, p. 69-70); the age of the Silver Plume is about 1,400 \pm 40 m.y. (Hedge, 1969, p. 81). This late deformation has only minor expression in the area of figure 2 (see zone of cataclastically deformed gneisses, Sheridan, Reed, and Bryant, 1972). The Pikes Peak Granite, youngest of the major Precambrian intrusives, was emplaced about 1,040 $\pm 10 \mathrm{~m} . \mathrm{y}$. ago (Hedge, 1969, p. 83). Late in Precambrian time extensive northwest-trending faults-the "breccia reefs" of Lovering and Goddard (1950, p. 79)-were formed (Tweto and Sims, 1963, p. 1001); some were reactivated during the Laramide orogeny.

\section{PRECAMBRIAN METAMORPHIC ROCKS}

In addition to the rutile-bearing gneisses, metasedimentary and metavolcanic gneisses occur in the report area and are divided herein into five principal units, units $A$ to $E$ of figure 2. Because 
primary sedimentary and volcanic features have been largely obliterated by high-grade metamorphism, stratigraphic relations among the five units are unknown.

\section{SILLIMANTIC BIOTITE GNEISS (UNIT A)}

Rocks of unit A are approximately coextensive with the rutile-bearing gneisses (fig. 2). Unit A is composed of gray fine- to medium-grained sillimanitic biotite gneiss containing abundant darker gray layers, $60 \mathrm{~cm}$ to $15 \mathrm{~m}$ thick, of garnetiferous sillimanitic biotite gneiss and of cordierite-bearing sillimanitic biotite gneiss. Lenses of dark-colored coarse-grained cordierite-gedrite-garnet gneiss, $60 \mathrm{~cm}$ to $15 \mathrm{~m}$ thick, are present locally.

\section{BIOTITE GNEISS (UNIT B)}

Thick sections of unit B, biotite gneiss, occur in the southwestern part of the area (fig. 2). There and in the northwestern part of the area the adjacent rocks are commonly hornblende gneiss and associated rocks of unit D. In general lithology, unit B is somewhat similar to unit $\mathrm{A}$ but lacks the abundance of dark-colored layers of garnet-rich gneiss and cordierite-bearing gneiss. Unit B is composed of fineto medium-grained light- to medium-gray strongly foliated biotite gneiss containing 10-50 percent mica, with biotite generally predominant over muscovite. Two major varieties, commonly as alternating layers a few centimetres to $15 \mathrm{~m}$ thick, are biotite-quartzplagioclase gneiss and sillimanitic biotite-quartz gneiss. Some of the rocks are microcline-bearing and some are sparsely garnetiferous. Lenses of calc-silicate rock occur locally. Thin conformable seams of granitic material are abundant locally but are usually erratically distributed in this map unit. Granitic material, however, forms 25 to 50 percent of an especially migmatitic variety of biotite gneiss in the northeastern part of the area.

\section{INTERLAYERED FELDSPAR-RICH GNEISS,} HORNBLENDE GNEISS, AND AMPHIBOLITE (UNIT C)

Unit C is composed of feldspar-rich gneiss, hornblende gneiss, and amphibolite similar to those of units $\mathrm{D}$ and $\mathrm{E}$, with which unit $\mathrm{C}$ is intercalated. In unit $\mathrm{C}$ these rocks are interlayered in approximately equal thicknesses on a scale of several centimetres to $10 \mathrm{~m}$ or more; locally one or another rock type predominates. Interlayers of medium- to dark-gray biotite-quartz-plagioclase gneiss are locally abundant. Layers and lenses of the relatively dark-colored hornblende gneiss, amphibolite, and biotite gneiss are common in the feldspar-rich gneiss (unit E), but even in unit $\mathrm{E}$ they form less than 25 percent of the total rock exposed.

\section{HORNBLENDE GNEISS AND AMPHIBOLITE (UNIT D)}

The rocks of Unit $\mathrm{D}$ are commonly interlayered on a scale ranging from $30 \mathrm{~cm}$ to $30 \mathrm{~m}$. Hornblende gneiss and amphibolite are dominant, but interlayers of calc-silicate gneiss, impure marble, and quartz gneiss are common in the southern half of the area. Cordierite-bearing biotite gneiss is common as interlayers in unit D shown terminating westward against unit B (fig. 2). Feldspar-rich gneiss, especially the medium-gray plagioclase-rich variety, is also present in parts of unit $\mathrm{D}$.

Fine- to medium-grained medium- to dark-gray or greenish-gray hornblende gneiss contains, in addition to hornblende and plagioclase, 15 percent or more of other minerals-clinopyroxene, quartz, biotite, or epidote-group minerals. Compositional layers range in thickness from $6 \mathrm{~mm}$ to a metre or more; parallel planar alinement of hornblende defines the foliation. Fine- to medium-grained dark-green to black amphibolite, consisting predominantly of hornblende and plagioclase, is unlayered but variably foliated. Fine- to coarse-grained calc-silicate gneiss displays a well-developed compositional layering on a scale of a millimetre to a metre. Colors of the calc-silicate gneiss are dark gray, light green, yellowish green, white, gray, pinkish, or black, depending upon the various proportions of plagioclase, hornblende,epidote, clinopyroxene, microcline, quartz, sphene, garnet, calcite, vesuvianite, scapolite, cummingtonite, tremolite, and magnetite-ilmenite. The coarse-grained variety of calc-silicate gneiss is common as pods or lenses rich in garnet, epidote, and quartz. Lenses of medium-grained impure marble are abundant locally and contain garnet, epidote, clinopyroxene, and other minerals of the calc-silicate gneiss assemblages in addition to calcite. Lenses and layers of fine-grained quartz gneiss are common near contacts with other rock units, range in thickness from 0.3 to $6 \mathrm{~m}$ and contain variable amounts of magnetite-ilmenite and garnet. Fine- to medium-grained biotite gneiss contains cordierite, variable amounts of sillimanite, and palebrown biotite.

\section{FELDSPAR-RICH GNEISS (UNIT E)}

Unit $\mathrm{E}$ is composed of fine- to medium-grained lightto medium-gray, tan, or pinkish-gray feldspar-rich gneiss and is characterized by the predominance of feldspar and quartz over biotite. A closely spaced foliation is formed by planar alinement of biotite, which commonly forms less than 10 percent of the rock 


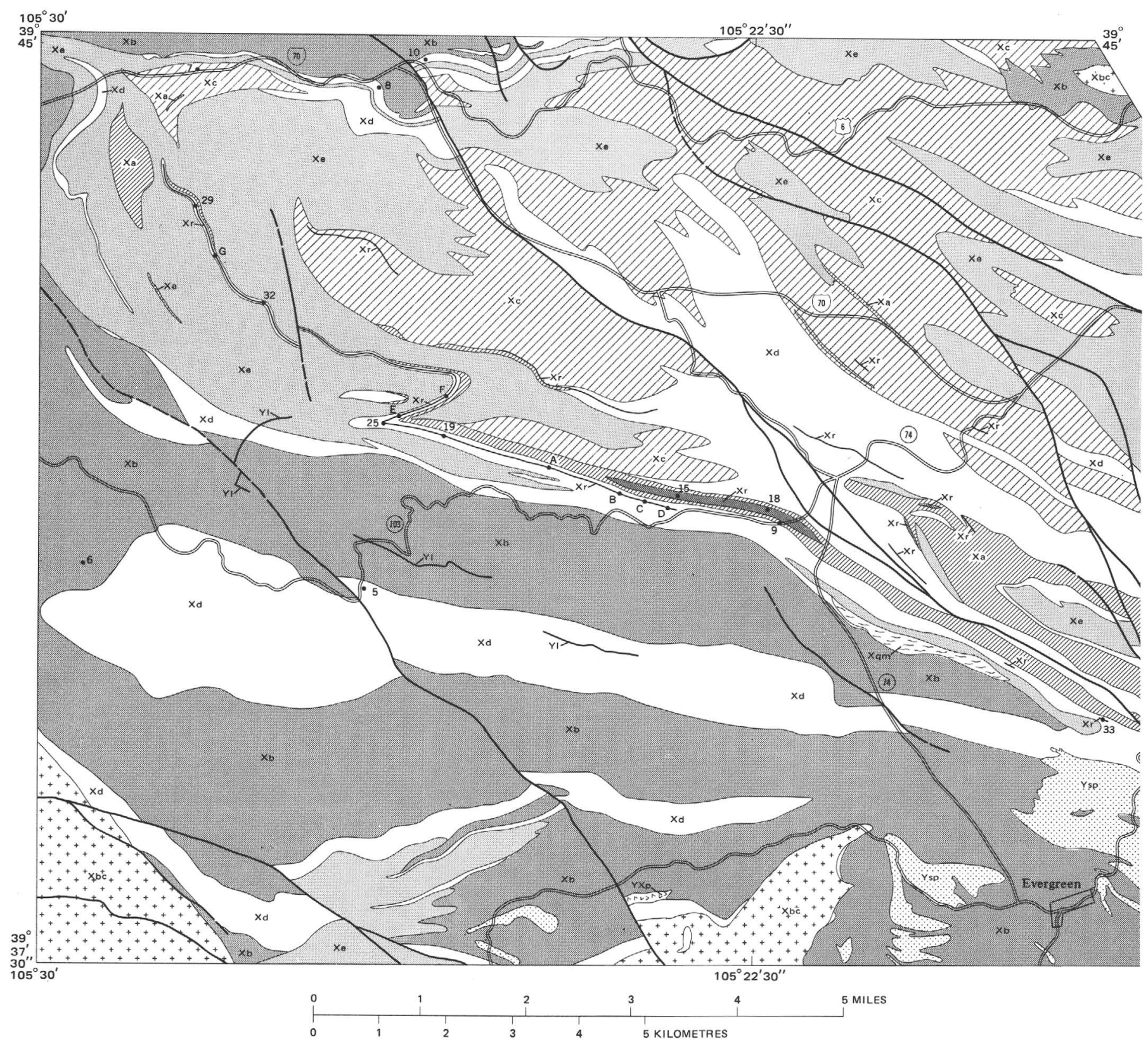

Figure 2.-Generalized geologic map showing distribution of

though locally as much as 15 percent. Light-colored granitic-appearing varieties of the rock contain as much as 50 percent microcline; somewhat darker plagioclase-rich varieties contain only traces of microcline. Conformable dark layers and lenses of hornblende gneiss, amphibolite, or biotite-quartzplagioclase gneiss, $13 \mathrm{~mm}$ to a metre or more thick, are locally abundant but generally are not continuous for more than $100 \mathrm{~m}$. Much of the feldspar-rich gneiss is similar to rocks mapped as microcline-quartz-plagioclase-biotite gneiss in nearby areas (Moench, 1964, p.
A19-A24; Sims and Gable, 1967, p. E8-E11; Sheridan, Maxwell, and Albee, 1967, p. 16-17).

\section{RUTILE-BEARING GNEISSES}

Several conformable layers and lenses of rutilebearing gneisses are shown in figure 2. The rutile-bearing gneisses are most commonly associated with rocks of units $\mathrm{A}$ and $\mathrm{D}$, and locally with unit C; some are along contacts between the main rock units. The longest and most continuous layers are in the western half of the area (fig. 2). The southwestern- 


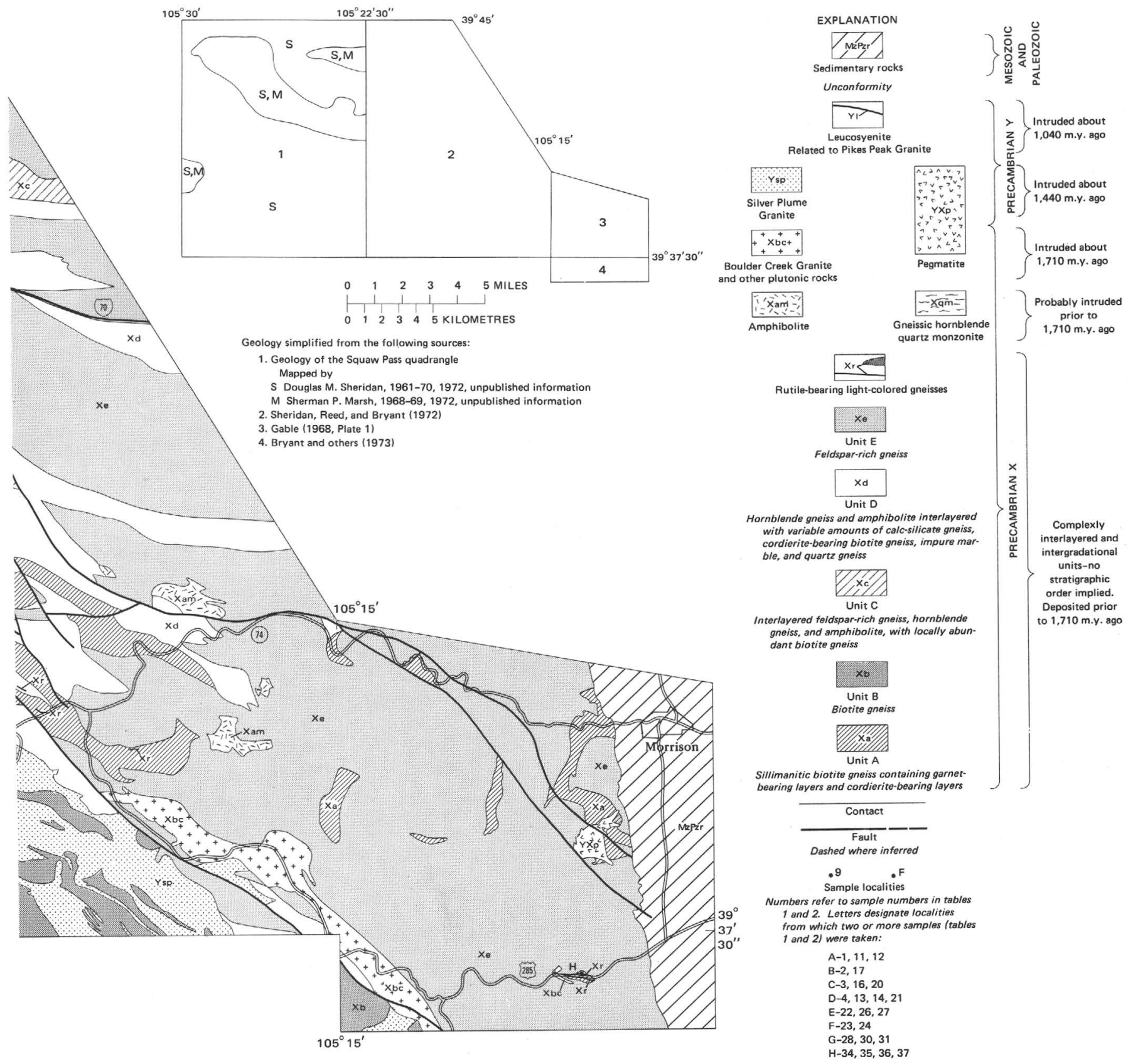

Precambrian rutile-bearing gneiss, east-central Front Range, Colo.

most layer ranges in thickness from $30 \mathrm{~cm}$ to $21 \mathrm{~m}$ and has an outcrop length of about $13 \mathrm{~km}$. About $0.15 \mathrm{~km}$ north of the eastern end of this layer is a rutilebearing lens $3.5 \mathrm{~km}$ long and as much as $150 \mathrm{~m}$ thick; this lens is actually composed of numerous smaller lenses of rutile-bearing gneiss, 6 to $30 \mathrm{~m}$ thick, separated by variable amounts of sillimanite-rich biotite gneiss. In the area between the southwesternmost layer and Interstate Highway 70 are three other lenses of rutile-bearing gneiss, ranging in length from 2 to $3 \mathrm{~km}$ and in thickness from $30 \mathrm{~cm}$ to $9 \mathrm{~m}$. Other lenses shown on figure 2 are short; they range in length from 60 to $780 \mathrm{~m}$ and in thickness from $15 \mathrm{~cm}$ to $30 \mathrm{~m}$.

The rutile-bearing gneisses are generally lighter in color than the adjacent rocks. Whereas this characteristic is a useful megascopic feature when doing field studies in this region, it is by no means infallible. Other light-colored Precambrian rocks which occur similarly as thin layers and lenses but which are generally devoid of rutile are numerous varieties of feldspar-rich gneiss, calc-silicate gneiss, 
cordierite-bearing biotite gneiss, and quartz gneiss as well as pegmatite and aplite. A hand lens is nearly always necessary to check for the presence or absence of tiny splendent grains of rutile, which most commonly is red but which also can be black, orange, or pale orange-yellow; the rutile grains are generally anhedral and less than $0.5 \mathrm{~mm}$ in size. Sillimanite is commonly present in noteworthy amounts in several varieties of rutile-bearing gneiss. Although some of these gneisses resemble other layered quartz gneisses which are common in this region, they lack the magnetite, ilmenite, or garnet which usually occur in the local quartz gneisses. Where biotite is present, it commonly is pale brown under the hand lens in contrast to its black color in most biotite gneisses and feldspar-rich gneisses of the region. Generally, the biotite content of rutile-bearing gneiss is less than that of the more common biotite gneisses of the region.

The rutile-bearing gneisses are generally fine- to medium-grained; some appear coarse grained owing to the presence of large crystals of prismatic sillimanite and, more rarely, corundum in a fine- to medium-grained matrix. Some of the lenses are composed of one variety of gneiss but most layers and lenses are composed of several interlayered and intergradational varieties. Most common among the varieties are biotite-quartz-plagioclase gneiss, sillimanite-quartz gneiss, and rocks gradational between these two. In these rocks rutile commonly occurs in amounts of 0.5 percent or less but locally as much as 2 percent. Rutile-bearing sillimanitic topaz-quartz gneiss is the principal variety in the eastern part of the longest rutile-bearing layer (from sample locality A to D, fig. 2), in short lenses at and near sample locality 33 , and in two partially exposed layers or lenses at sample locality $\mathrm{H}$. The rutile content of the sillimanitic topaz-quartz gneiss is commonly in the range 1 to 2.5 percent and locally is about 5 percent.

Rutile-bearing biotite-quartz-plagioclase gneiss is a light-gray moderately well-foliated rock that is rich in plagioclase (commonly 45 to 55 percent). The plagioclase is albite-oligoclase rather than the oligoclase-andesine usually found in other biotite gneisses and feldspar-rich gneisses of the region. Biotite, most often a pale-brown phlogopitic variety, generally comprises less than 15 percent of the gneiss. Locally the gneiss grades to a darker gray color, corresponding to the presence of some layers containing black biotite. Andalusite, in blocky grains of $1 \mathrm{~mm}$ or less, is present locally as a rare accessory mineral. As viewed in thin section (fig. 3) subparallel grains of biotite define the foliation in rutile-bearing biotite-quartz-plagioclase gneiss; elongate grains of rutile are alined parallel to the foliation.
Rutile-bearing sillimanite-quartz gneiss is a white to creamy-white rock consisting dominantly of quartz and typically 20 to 30 percent sillimanite. The rock might also be called a sillimanitic quartzite because feldspar is rarely present in noteworthy amounts except in rock gradational to biotite gneiss. Muscovite is more common than biotite but the total mica content is generally less than 2 percent. The sillimanite is in fibrolitic needles that form interlensing laminae between thin granular quartz septa, giving the rock a thinly layered and moderately well-foliated appearance. As viewed in thin section (fig. 4), elongate grains of rutile are alined parallel to the foliation defined by the fibrolitic sillimanite.

Rutile-bearing gneisses gradational in composition between sillimanite-quartz gneiss and biotite-quartzplagioclase gneiss are light gray to gray and moderately to well foliated. Although the principal minerals occur in variable amounts, most commonly quartz predominates greatly over plagioclase, sillimanite ranges from 5 to 20 percent, and biotite is 15 percent or less.

Rutile-bearing sillimanitic topaz-quartz gneiss is a white fine- to medium-grained rock composed chiefly of quartz and topaz and lesser amounts of sillimanite, rutile, and apatite; muscovite and zircon are accessory minerals. Medium-grained white or glassy quartz layers $2 \mathrm{~mm}$ to $4 \mathrm{~cm}$ thick alternate with discontinuous thinner layers of finer grained creamy granular topaz-rutile rock and with radiating coarse-grained aggregates of prismatic sillimanite. The rock is similar in appearance to a layered sillimanitic quartzite and is not readily distinguished except by its greater heft, owing to the high specific gravity of topaz $(\approx 3.5)$. Rutile commonly is concentrated in thin layers colored pale reddish by the tiny splendent rutile crystals. Samples of the gneiss contain rutile in amounts ranging from 0.3 to 5.3 percent $\left(\mathrm{Ti0}_{2}\right.$ determined by $\mathrm{X}$-ray fluorescence) and topaz from 22 to 67 percent (mineral separation by heavy liquid). Fibrolitic sillimanite forms a linear orientation in some sillimanitic quartz laminae. Prismatic crystals of sillimanite, as much as 2 square $\mathrm{mm}$ in cross-sectional area and $3 \mathrm{~cm}$ in length, are in irregular to radiating aggregates flattened parallel to the layering but they lack linear orientation. Locally the gneiss contains thin laminae as much as $\mathbf{5 m}$ thick composed of a green crhomium-bearing muscovite. Viewed microscopically, fibrolitic sillimanite is partly replaced by topaz and is partly recrystallized to large grains of prismatic sillimanite (fig. 5); rutile is molded around topaz grains (fig. 6) and is intergrown with prismatic sillimanite (fig. 7). Thin seams of kaolinite were seen in thin sections of gneiss obtained from sample locality 


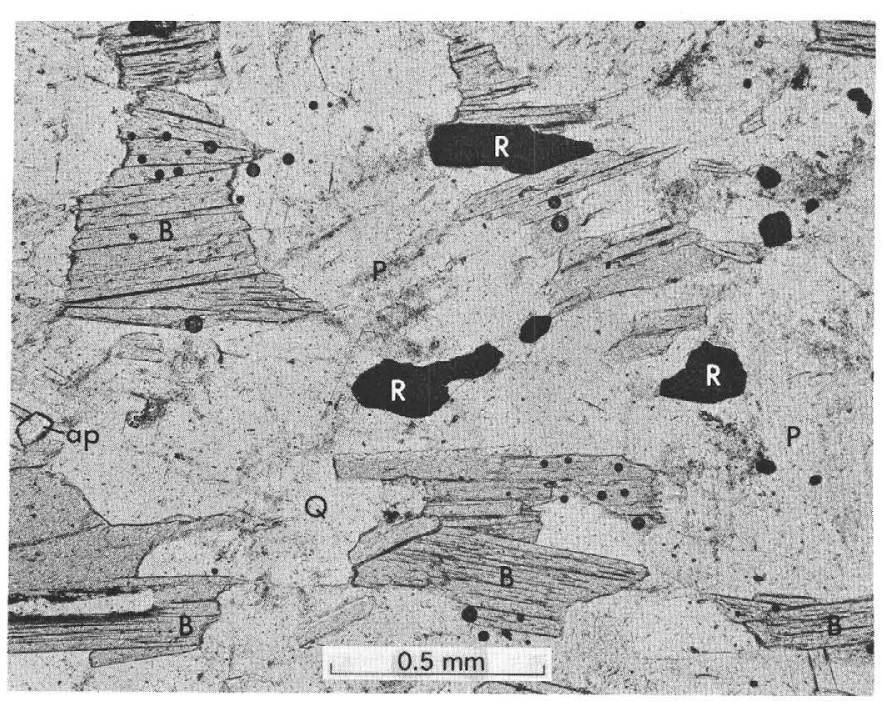

F IGURE 3.-Photomicrograph of elongate grains of rutile (R) alined parallel to foliation defined by planar alinement of biotite (B) in biotite-quartz-plagioclase gneiss from sample locality $\mathrm{F}$ (fig. 2). Other minerals are plagioclase (P), quartz $(Q)$, and apatite (ap). Plane-polarized light.

$\mathrm{H}$ and from a small lens $1 \mathrm{~km}$ east-southeast of sample locality 33 (fig. 2).

A local variant of the more common types of rutilebearing gneiss is a corundum-bearing sillimaniteplagioclase gneiss which occurs as lenses in rutilebearing biotite-quartz-plagioclase gneiss at sample locality $\mathrm{G}$ and also $0.3 \mathrm{~km}$ northwest of sample locality 29 (fig. 2). The sillimanite-plagioclase gneiss is a white or light-gray fine- to coarse-grained rock that is poorly

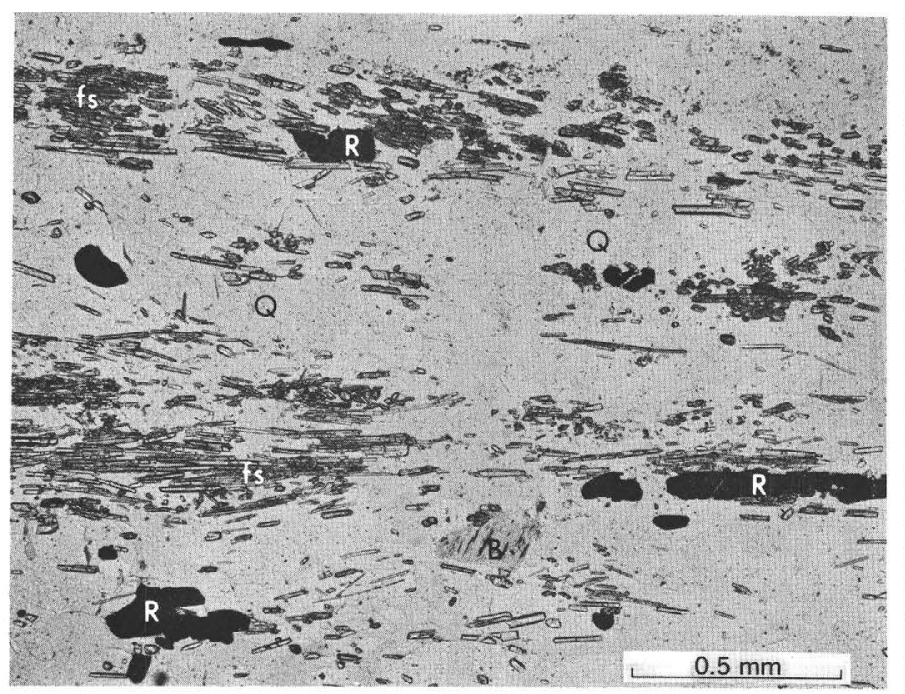

Figure 4.-Photomicrograph of elongate grains of rutile (R) alined parallel to foliation defined by alinement of fibrolitic sillimanite ( $f s$ ) in sillimanite-quartz gneiss from sample locality 25 (fig. 2). Other minerals are quartz (Q) and biotite (B). Planepolarized light.

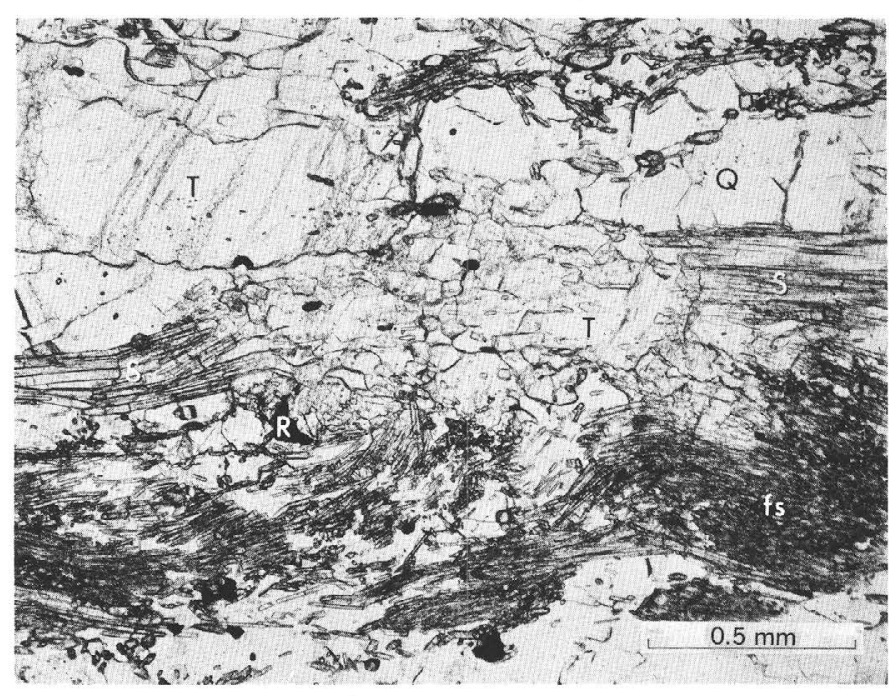

FIGURE 5.-Photomicrograph of fibrolitic sillimanite ( $f s$ ) partly replaced by topaz $(T)$ and partly recrystallized to prismatic sillimanite (S) in sillimanitic topaz-quartz gneiss from sample locality $\mathrm{D}$ (fig. 2). Other minerals are quartz ( $\mathrm{Q})$ and the rutile (R). Planepolarized light.

foliated and texturally complex. Grains of pinkish to gray corundum, as long as $2.3 \mathrm{~cm}$, and aggregates of prismatic sillimanite, as much as $12 \mathrm{~cm}$ long and $1 \mathrm{~cm}$ thick, are diversely oriented in a fine- to medium-grained matrix rich in plagioclase (albite, $\mathrm{An}_{6-8}$ ) and fibrolitic sillimanite. Rutile forms 1 to 2 percent of the gneiss (mineral separations and thinsection modal analyses, 1,000 points each). At locality $\mathrm{G}$ the corundum-bearing gneiss contains wagnerite, a rare magnesium fluophosphate (Sheridan, Marsh and others, 1971). Other constituents of the gneiss are muscovite, apatite, monazite, zircon, tourmaline, and

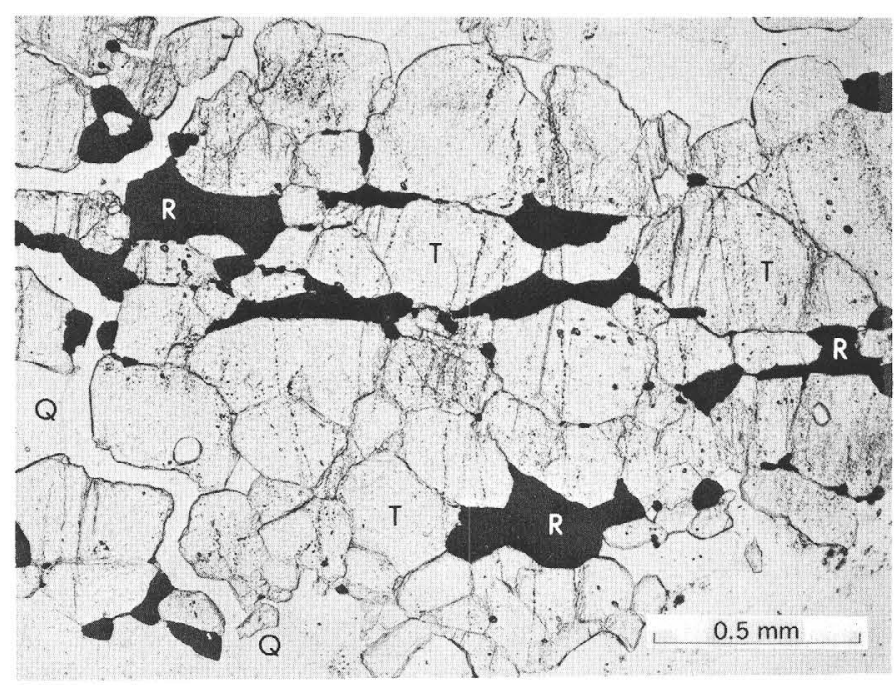

FIGURE 6.-Photomicrograph of rutile (R) associated with topaz (T)in topaz-quartz gneiss from sample locality B (fig. 2). Other mineral is quartz $(Q)$. Plane-polarized light. 


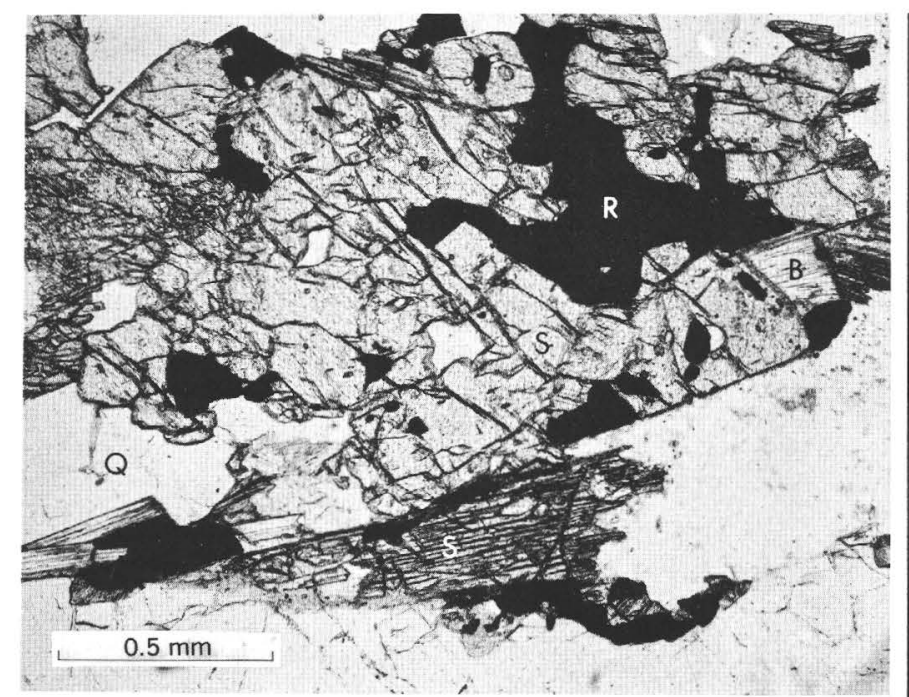

Figure 7.-Photomicrograph of prismatic sillimanite (S) intergrown with rutile $(R)$ in sillimanite-quartz gneiss that occurs as a layer in sillimanitic topaz-quartz gneiss at sample locality $\mathrm{D}$ (fig. $2)$. Other minerals are quartz $(\mathrm{Q})$, and biotite (B). Planepolarized light.

locally, chlorite. The tourmaline is in small yellowish-brown to pale-greenish-blue grains having refractive indices that suggest the mineral to be dravite. Foliation in the sillimanite-plagioclase gneiss is commonly obscure in the outcrops, owing to the diversely oriented large grains of corundum and aggregates of prismatic sillimanite. The foliation, however, is well shown in some thin sections and is defined by elongate grains of plagioclase, aggregates of fibrolitic sillimanite, and oriented flakes of pale-brown biotite. Tiny anhedral grains of rutile are alined in rows parallel to this foliation. Larger grains of rutile are subhedral and are associated with corundum (fig. 8).

Layered hornblende gneiss associated in many areas with the light-colored rutile-bearing gneisses typically contain sphene and magnetite-ilmenite but no rutile. One exception to this occurs at locality G, where the hornblende gneiss adjacent to rutilebearing light-colored gneiss also contains rutile in addition to sphene and magnetite-ilmenite.

\section{CHEMICAL COMPOSITION}

Chemical and spectrographic analyses of four samples of rutile-bearing sillimanitic topaz-quartz gneiss and of six samples representing other lithologic types of Precambrian metamorphic rock are shown in table 1. The localities from which the samples were obtained are indicated in figure 2.

The analyses of rutile-bearing sillimanitic topazquartz gneiss show this to be a rather unusual rock,

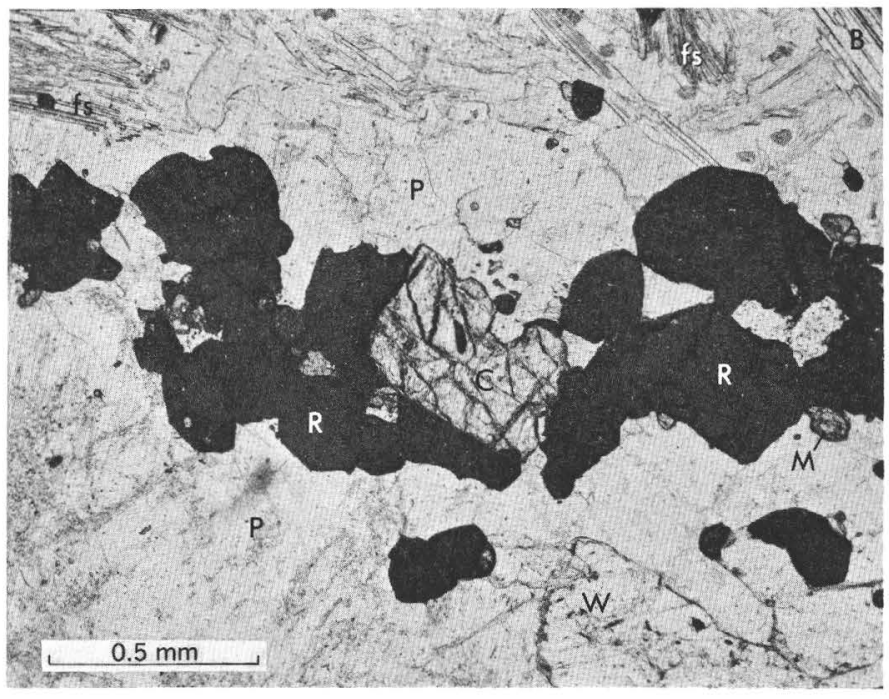

F IGURE 8.-Photomicrograph of subhedral grains of rutile (R) associated with blocky grain of corundum (C) in sillimaniteplagioclase gneiss from sample locality G (fig. 2). Other minerals are plagioclase $(P)$, fibrolitic sillimanite $(f s)$, biotite $(B)$, monazite (M), and wagnerite (W). Plane-polarized light.

for it is rich in silica (63-76 percent), alumina (18-27 percent), and fluorine (4-7.5 percent) and contains 1.47-2.76 percent titanium oxide. The rock contains little iron, alkali metals, and alkaline earths, reflecting the fact that, unlike many other quartz-rich rocks of the Front Range, it contains no magnetite, ilmentite, or garnet and very little biotite and feldspar. Small amounts of $\mathrm{CaO}$ and $\mathrm{P}_{2} \mathrm{O}_{5}$ are present as accessory apatite, and small amounts of zirconium are present as accessory zircon. Small amounts of rare earths may be in monazite. Although monazite was not identified in thin sections of topaz-quartz gneiss, it has been found as an accessory mineral in other types of rutile-bearing gneiss. Small amounts of chromium are in green chromium-bearing muscovite found as thin laminae in some of the sillimanitic topaz-quartz gneiss. A sample of material rich in this green mica from sample locality $\mathrm{H}$ (fig. 2) contains 0.2 percent $\mathrm{Cr}_{2} \mathrm{O}_{3}$, as determined by J. S. Wahlberg, U.S. Geological Survey, by X-ray fluorescence.

The petrography of the rutile-bearing sillimanitequartz gneiss indicates high silica and alumina, accessory titania, and very little of any other constituents. The rutile-bearing biotite-quartz-plagioclase gneiss is somewhat richer in $\mathrm{Na}$ and poorer in $\mathrm{Ca}$ than other biotite gneisses of the east-central Front Range. Also, it probably is richer in $\mathrm{Mg}$ and poorer in $\mathrm{Fe}$ than most other biotite gneisses. Corundumbearing sillimanite-plagioclase gneiss is an aluminarich rock also characterized by high $\mathrm{Na}$ and $\mathrm{Mg}$ relative to $\mathrm{Ca}$ and $\mathrm{Fe}$. 
TABLE 1.-Analytical data for rutile-bearing gneiss and for other Precambrian metamorphic rocks, east-central Front Range, Colorado

\begin{tabular}{|c|c|c|c|c|c|c|c|c|c|c|}
\hline \multicolumn{5}{|c|}{ Rock type ... Rutile-bearing sillimanitic topaz-quartz gneiss ${ }^{1}$} & \multicolumn{6}{|c|}{ Other Precambrian metamorphic rocks ${ }^{2}$} \\
\hline Sample No. & $1(\mathrm{~A})$ & $2(B)$ & $3(\mathrm{C})$ & $4(D)$ & 5 & 6 & 7 & 8 & 9 & 10 \\
\hline $\begin{array}{l}\text { Laboratory } \\
\text { serial no ... }\end{array}$ & D102280 & D102281 & D102282 & D102283 & D127511W & D127512W & D127516W & D127517W & D127518W & D127519W \\
\hline Field no.... & R-22A & R-23A & R-24A & R-25A & S-C-6 & S-C-7 & S-C-11 & S-C-13 & S-C-14 & $\overline{\text { S-C-15a }}$ \\
\hline
\end{tabular}

Chemical analyses (weight percent)
[Analyses of sample 1-4 are standard rock analyses by Elaine L. Munson. Analyses of samples 5-10, except for fluorine determinations, are rapid-rock analyses by Paul Elmore, Samuel Botts, Gillison Chloe, John Glenn, Lowell Artis, and Hezekiah Smith. Fluorine determinations in samples 5-10 are by Johnnie Gardner and Adolph Haubert using specific ion electrode method. All analysts are affiliated with the U.S. Geological Survey. Dashed line in table indicates no data]

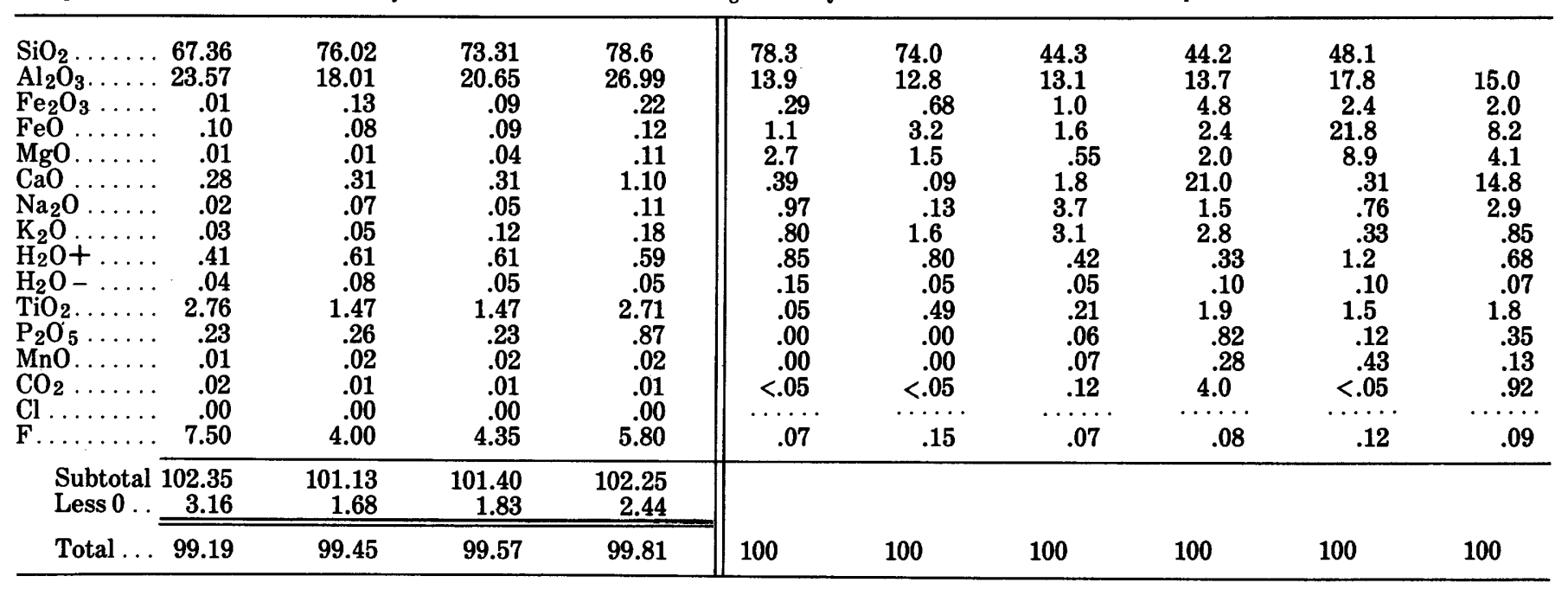

Semiquantitative epectrographic analyses (parts per million) ${ }^{3}$

[Analyses of samples 1-4 by R. H. Heidel, U.S. Geological Survey. Analyses of samples 5-10 by G. W. Sears, Jr., U.S. Geological Survey]

\begin{tabular}{|c|c|c|c|c|c|c|c|c|c|c|}
\hline $\begin{array}{l}\mathrm{Ba} \\
\mathrm{Be} \\
\mathrm{Ce} \\
\mathrm{Co} \\
\mathrm{Cr} \\
\mathrm{Cu} \\
\mathrm{Ga} \\
\mathrm{La} \\
\mathrm{Nb} \\
\mathrm{Nd} \\
\mathrm{Ni} \\
\mathrm{Pb} \\
\mathrm{Sc} \\
\mathrm{Sr} \\
\mathrm{V} \\
\mathrm{Y} \\
\mathrm{Yb} \\
\mathrm{Zn} \\
\mathrm{Zr}\end{array}$ & $\begin{array}{r}7 \\
N \\
N \\
N \\
70 \\
70 \\
N \\
N \\
\text { L } \\
\text { N } \\
\text { N } \\
\text { L } \\
10 \\
7 \\
70 \\
30 \\
1 \\
N \\
300\end{array}$ & $\begin{array}{r}7 \\
\mathbf{N} \\
\mathbf{N} \\
\mathbf{N} \\
\mathbf{1 5} \\
\mathbf{3} \\
\mathbf{5} \\
\mathbf{N} \\
\mathrm{L} \\
\mathbf{N} \\
\mathbf{N} \\
\mathbf{N} \\
\mathbf{5} \\
\mathbf{N} \\
\mathbf{3 0} \\
\mathbf{1 0} \\
\mathbf{2} \\
\mathbf{N} \\
\mathbf{1 5 0}\end{array}$ & $\begin{array}{r}70 \\
\mathbf{N} \\
\mathbf{N} \\
\mathbf{N} \\
7 \\
\mathbf{3} \\
\mathbf{5} \\
\mathbf{N} \\
\mathbf{1 0} \\
\mathbf{N} \\
\mathbf{N} \\
\mathbf{N} \\
\mathbf{1 5} \\
\mathbf{7} \\
\mathbf{3 0} \\
\mathbf{3 0} \\
\mathbf{3} \\
\mathbf{N} \\
\mathbf{1 5 0}\end{array}$ & $\begin{array}{r}150 \\
\mathbf{N} \\
300 \\
\mathbf{N} \\
10 \\
7 \\
5 \\
150 \\
\mathrm{~L} \\
200 \\
\mathrm{~N} \\
\mathrm{~N} \\
30 \\
15 \\
70 \\
70 \\
7 \\
\mathrm{~N} \\
700\end{array}$ & $\begin{array}{r}150 \\
\mathbf{2} \\
\mathbf{N} \\
\mathbf{N} \\
\mathbf{1} \\
<1 \\
20 \\
30 \\
\mathbf{N} \\
\mathbf{N} \\
\mathbf{N} \\
\mathbf{1 5} \\
\mathbf{N} \\
\mathbf{7 0} \\
\mathbf{N} \\
20 \\
\mathbf{3} \\
\mathbf{N} \\
\mathbf{7 0}\end{array}$ & $\begin{array}{r}300 \\
\mathbf{N} \\
\mathbf{N} \\
\mathbf{1 0} \\
\mathbf{3 0} \\
\mathbf{5 0} \\
\mathbf{3 0} \\
\mathbf{5 0} \\
\mathbf{1 0} \\
\mathbf{N} \\
\mathbf{1 0} \\
\mathbf{N} \\
\mathbf{1 5} \\
\mathbf{7} \\
\mathbf{7 0} \\
\mathbf{2 0} \\
\mathbf{3} \\
\mathbf{N} \\
\mathbf{1 5 0}\end{array}$ & $\begin{array}{r}500 \\
\mathbf{1} \\
\mathbf{N} \\
\mathbf{N} \\
\mathbf{1} \\
\mathbf{N} \\
\mathbf{2 0} \\
\mathbf{N} \\
\mathbf{1 0} \\
\mathbf{N} \\
\mathbf{N} \\
\mathbf{1 5} \\
\mathbf{7} \\
\mathbf{7 0} \\
\mathbf{N} \\
\mathbf{7 0} \\
\mathbf{7} \\
\mathbf{N} \\
\mathbf{2 0 0}\end{array}$ & $\begin{array}{r}\mathbf{3 0 0} \\
\mathbf{N} \\
\mathbf{N} \\
\mathbf{2 0} \\
\mathbf{1 5 0} \\
\mathbf{5} \\
\mathbf{2 0} \\
\mathbf{3 0} \\
\mathbf{1 0} \\
\mathbf{N} \\
\mathbf{5 0} \\
\mathbf{1 0} \\
\mathbf{2 0} \\
\mathbf{3 0 0} \\
\mathbf{1 5 0} \\
\mathbf{3 0} \\
<\mathbf{3} \\
\mathbf{N} \\
\mathbf{1 5 0}\end{array}$ & $\begin{array}{r}\mathbf{3 0} \\
\mathbf{N} \\
\mathbf{N} \\
\mathbf{1 5} \\
\mathbf{3 0} \\
\mathbf{1} \\
\mathbf{2 0} \\
\mathbf{N} \\
\mathbf{N} \\
\ldots \\
\mathbf{1 5} \\
\mathbf{N} \\
\mathbf{3 0} \\
\mathbf{5} \\
\mathbf{2 0 0} \\
\mathbf{1 5} \\
<\mathbf{3} \\
\mathbf{3 0 0} \\
\mathbf{2 0}\end{array}$ & $\begin{array}{r}50 \\
\mathbf{N} \\
\mathbf{N} \\
50 \\
150 \\
30 \\
20 \\
\mathbf{N} \\
\mathbf{N} \\
\ldots \\
30 \\
\mathbf{N} \\
30 \\
300 \\
300 \\
30 \\
<3 \\
\mathbf{N} \\
70\end{array}$ \\
\hline
\end{tabular}

1 All samples are splits of bulk samples, originally about 50 pounds $(22.7 \mathrm{~kg})$ in the table each. Each of the bulk samples was obtained by taking a composite sample across the exposed width of the rutile-bearing gneiss. Localities are shown in figure 2 . These localities, indicated in the table by letter symbols, (A) through (D) following the sample numbers designate localities from which two or more samples were taken and are shown

numbers 2 by the letter symbols only.
in figure 2 .
2 All samples are grab samples. Localities are shown in figure 2. The lithology All samples are grab samples. Localities are shown in figure 2. The lithology
represented by each of these samples is as follows: Sample 5, Biotite-quartz-plagioclase represented by each of these samples is as follows: Sample 5, Biotite-quartz-plagioclase gneiss containing cordierite and sillimanite; 6, Sillimanitic biotite-quartz gneiss; 7,
Microcline-quartz-plagioclase-biotite gneiss; 8, Calc-silicate gneiss; 9 , Gedrite-

3 Minor elements were determined by semiquantitative spectrographic methods described by Myers and others (1961). Results of the spectrographic analyses are to be identified with geometric intervals having the boundaries $1200,830,560,380,260,180$, 120 , etc., in parts per million but are reported arbitrarily in the table by approximate geometric midpoints such as $1000,700,500,300,200,150,100$, etc. Precision of a reported value is approximately plus-or-minus one interval at 68-percent confidence, or plus-or-minus two intervals at 95-ercent confidence. $\mathrm{N}$, not detected at limit of Microcline-quartz-plagioclase-biotite gneiss;
cordierite-garnet gneiss; 10 , Hornblende gneiss.

Analyses of six other Precambrian metamorphic composition of some of the other lithologies in the area of rutile-bearing gneisses. Samples 5,6 , and 7 represent, respectively, cordierite-bearing sillimanitic rocks are given in table 1 to illustrate the biotite gneiss, sillimanitic biotite gneiss, and feldspar- 
rich gneiss; they contain only 0.05 to 0.49 percent $\mathrm{TiO}_{2}$. Samples 8,9 , and 10 represent, respectively, calcsilicate gneiss, gedrite-cordierite-garnet gneiss, and hornblende gneiss; they contain 1.5 to 1.9 percent $\mathrm{TiO}_{2}$, amounts that are comparable to $\mathrm{TiO}_{2}$ in some rutile-bearing sillimanitic topaz-quartz gneiss. Except for a rare occurrence of rutile in hornblende gneiss at locality $\mathrm{G}$, no rutile has been observed in these rocks. Petrographic studies of hornblende gneiss and calc-silicate gneiss indicate that sphene and magnetite-ilmenite are common accessory minerals and probably account for much of the $\mathrm{TiO}_{2}$ reported. Opaque iron oxides in gedrite-cordierite-garnet gneiss may be ilmenite or magnetite-ilmenite. Some of the titanium in these rocks probably is in biotite, amphibole, and other minerals but detailed analytical studies of minerals have not been made. The fluorine content of samples 5 through 10 ranges from 0.07 to 0.15 percent, or 700 to $1,500 \mathrm{ppm}$. This range falls within the range, 60 to $1,500 \mathrm{ppm}$, reported by Fleischer and Robinson (1963, p. 63) but is higher than the average, $380 \mathrm{ppm}$, of 69 analyses of metamorphic rocks compiled from the literature.

\section{GEOCHEMISTRY OF RUTLE}

Stringent regulations imposed by the Office of Emergency Planning concerning chemical impurities in rutile and the lack of published information on trace elements in rutile prompted a study of rutile specimens from the Evergreen locality and several other localities where similar environments are found. Twenty-nine samples of rutile from the east-central part of the Front Range, and eleven samples from three other United States localities were anlayzed spectrographically and the results are reported in table 2. These analyses show the similarities of trace-element content in rutile samples from similar environments in several areas of the United States and also show chemical impurities. A table of impurities permitted in rutile is used to demonstrate the usability of rutile from high-grade metamorphic environments. Following is a discussion of factors influencing the substitution of these trace elements in the rutile structure.

The rutile samples analyzed in this report, with the exception of crystals from Graves Mountain, Ga., were separated from whole rocks. Each Graves Mountain, Ga., sample is from large crystals that were sent to us by Mr. P. Bennett of Aluminum Silicates Inc., Washington, Ga. The rock samples were crushed, ground, washed, and sieved to $-65,+150$ mesh and then separated into light and heavy fractions by heavy liquids (bromoform). The heavy fraction was separated magnetically, and the nonmagnetic fraction was examined for rutile. The heavy nonmagnetic fraction commonly contains kyanite, andalusite, sillimanite, and topaz as well as rutile. Rutile grains were carefully hand-picked under a microscope and analyzed spectrographically. Most of the rutile in the whole-rock samples was in small anhedral grains, less than $0.5 \mathrm{~mm}$ across, and the color varied from black to pale orange-yellow. A few euhedral doubly terminated stubby prisms were seen, some of which exhibited the typical "knee shaped" rutile twins. Color is not consistent with a given sample and two or more colors are often present.

Impurities in the analyzed rutile ranged from iron, found in all samples, to cobalt, found only two. The maximum impurities permitted in rutile purchased by the United States Government are listed in table 3 as stipulated by the Office of Emergency Planning. Although a number of analyzed samples exceeded the limits for one or more of the listed impurities, many of these are due to sample contamination rather than impurities in the rutile. Calcium and magnesium are considered contaminants for two reasons: they do not fit into the rutile structure and they are not present in the single crystals from Graves Mountain, Ga. Zirconium was present in all samples analyzed except those from Graves Mountain. Zirconium can substitute for titanium but most zirconium contamination of the samples is probably due to zircon. Zircon was observed in most of the heavy, nonmagnetic fractions. Some of the samples from the east-central Front Range contained lanthanum. A comparison of samples $1(\mathrm{~A})$ and $4(\mathrm{D})$ in tables 1 and 2 indicates that the lanthanum is an impurity probably caused by monazite contamination. Small amounts of monazite were observed in the rocks. Antimony, tungsten, colbalt, and bismuth were also found in the analyzed rutile samples, although no standards of purity for these elements are given.

Most of the trace elements found in the analyzed samples can substitute into the rutile structure. These substitutions can be influenced by several factors (table 4). One element can substitute extensively for another, in this case titanium, if their atomic radii do not differ by more than 15 percent. If the radii differ by more than 15 percent, but the valence of the substituting ion is within one unit $\left(\mathrm{Ti}^{+4}\right)$, then some substitution may occur (Krauskopf, 1967, p. 585). Substitution may also occur if the ratio of the substituting ion to the ion being substituted for (titanium) is within limits determined by the structure of the mineral involved (Pauling, 1929). This ratio is expressed by $R_{A} / R_{X}$ where $R_{A}$ is the radius of the substituting metal ion and $R_{X}$ is the radius of the coordinating anion. Minerals having the rutile 
TABLE 2.-Semiquantitative spectrographic analyses rutile

[Analyses of samples R-1 to R-4, R-6 and R-7 by A. L. Sutton. All other analyses by E. O. Mosier. Elements were determined by semiquantitative spectrographic methods described by Myers and others (1961). Results of the spectrographic analyses are to be identified with geometric intervals having the boundaries 1200, 830, 560,380, 260, 180 120, etc.in parts per million but are reported arbitrarily in the table by approximate geometric midpoints such as $1000,700,500,300,200,150,100$, etc. Precision of a reported detected but below limit of determination. Localities in Colorado are shown on figure 2. Those localities indicated on the table by letter symbols (A) through $(\mathrm{H})$ after sample numbers designate localities from which two or more samples were taken and are shown on figure 2 by the letter symbols only. Other localities are indicated by numbers

Rutile from Evergreen area, east-central Front Range, Colo.

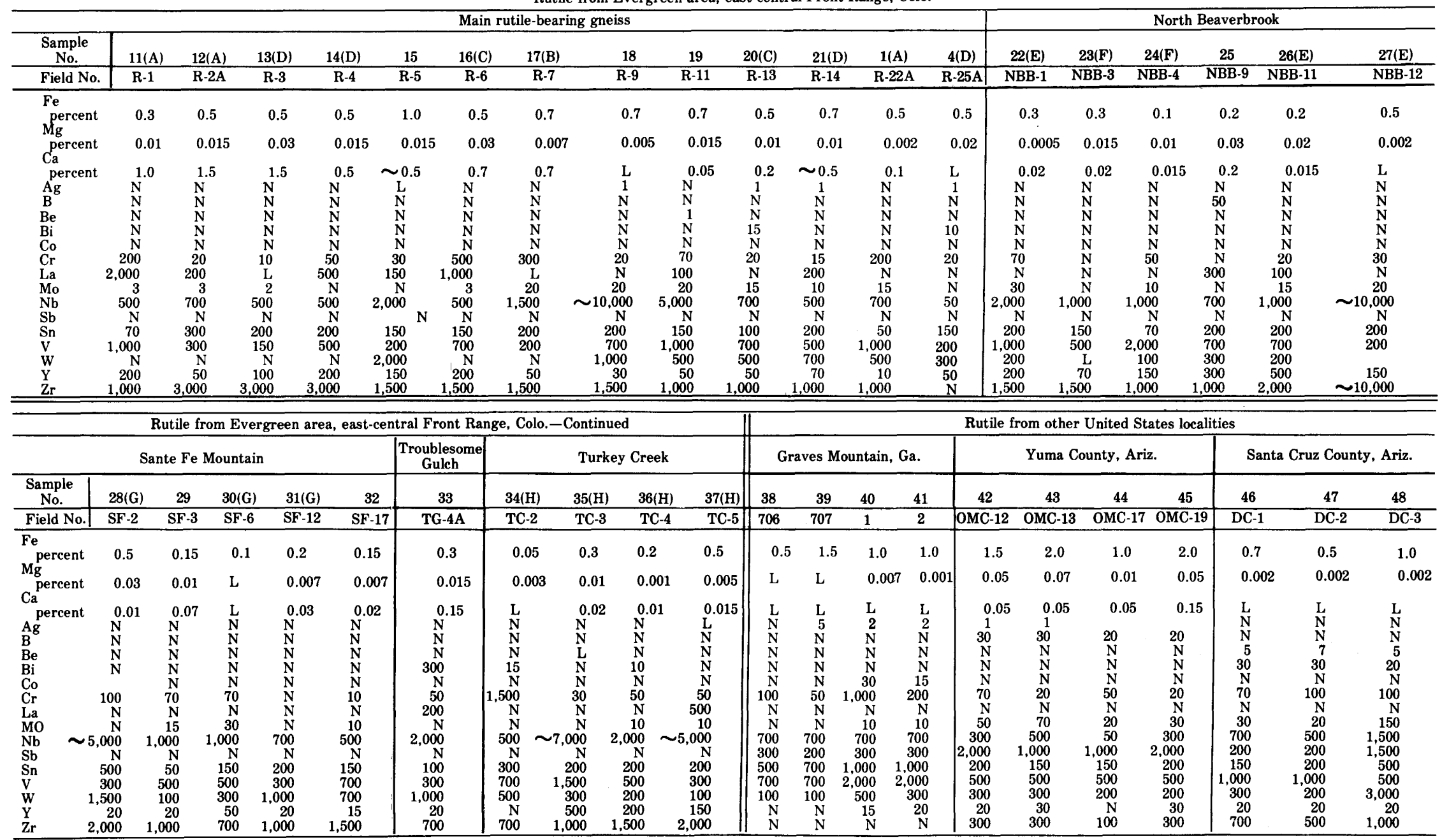


Table 3.-Standard of purity of rutile

[From National stockpile purchase specifications P-49-R5 (National Materials Advisory Board, 1972)]

\begin{tabular}{|c|c|}
\hline Impurity & $\begin{array}{l}\text { Weight percent } \\
\text { impurity permitted }\end{array}$ \\
\hline$\overline{\mathrm{Fe}_{2} \mathrm{O}_{3} \text {. }}$ & 1 \\
\hline $\mathrm{Nb}_{2} \mathrm{O}_{3}$ & .4 \\
\hline $\mathrm{ZrO}_{2} \ldots$ & 1 \\
\hline$\ldots \ldots \ldots \ldots \ldots \ldots \ldots \ldots \ldots$ & .75 \\
\hline $\mathrm{Cr} 203 \ldots \ldots \ldots \ldots \ldots \ldots \ldots \ldots \ldots \ldots \ldots$ & .75 \\
\hline $\mathrm{MgO}+\mathrm{CaO} \ldots \ldots \ldots \ldots \ldots \ldots \ldots \ldots \ldots \ldots$ & .25 \\
\hline 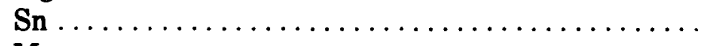 & .1 \\
\hline Mn & .75 \\
\hline
\end{tabular}

structure have radius ratios $\left(R_{A} / R_{X}\right)$ ranging from 0.41 to 0.73 for the octahedrally coordinated cations. In the rutile structure each cation is coordinated to six anions, and each anion forms a ligand to three cations. In the case of rutile, $R_{X}$ (for oxygen with a coordination number of three) equals $1.36 \mathrm{~A}$ (Shannon and Prewitt, 1969) and $R_{A}$ (for titanium with a coordination number of 6) equals $0.61 \mathrm{~A}$ (Shannon and Prewitt, 1969). This gives a radius ratio of $R_{A} / R_{X}=0.61 / 1.36=0.45$. Other octahedrally coordinated cations whose radii fall between the limiting radius ratio values of 0.41 and 0.73 can also substitute into the rutile structure. All but one of the elements listed in table 3 have radius ratios within the limits of the rutile structure and probably substitute for $\mathrm{Ti}$ in rutile. A fourth factor than can affect substitution into the rutile structure is that most of the trace elements found in the analyzed rutile belong to the transition elements and are related to titanium.

All the trace elements listed in table 3 satisfy one or more of the factors for substitution. Chrome, iron, molybdenum, niobium, and vanadium satisfy all four and all but chrome and molybdenum are found in every sample analyzed (table 2 ). These five elements also make up most of the trace elements found. A second group of elements found in trace amounts in rutile satisfy three of the four listed factors: tin, tungsten, yttrium, and zirconium. Elements satisfying

Table 4.-Ionic subsitution factors

[Elements are listed in order of decreasing likelihood of substitution]

\begin{tabular}{llccc}
\hline Element & $\begin{array}{l}\text { Valence } \\
(\mathrm{Ti}+4)\end{array}$ & $\begin{array}{c}\text { Ionic radius } \\
\text { I percent }=0.52 \text { to } 0.70\end{array}$ & $\begin{array}{c}\text { Radius ratio } \\
\mathrm{R}_{A} / \mathrm{R}_{X}\end{array}$ & $\begin{array}{c}\text { Transition } \\
\text { element }\end{array}$ \\
\hline Titanium & $\mathrm{Ti}+4$ & $\mathbf{0 . 6 1}$ & 0.45 & Yes \\
Iron & $\mathrm{Fe}+3$ & .64 & .47 & Yes \\
Niobium & $\mathrm{Nb}+3$ & .70 & .51 & Yes \\
Vanadium & $\mathrm{V}+4$ & .59 & .43 & Yes \\
Chrome & $\mathrm{Cr}+3$ & .62 & .45 & Yes \\
Molyb- & & & & \\
$\quad$ denum 2 & $\mathrm{Mo}+4$ & .64 & .48 & Yes \\
Tin & $\mathrm{Sn}+4$ & .69 & .51 & No \\
Tungsten & $\mathrm{W}+4$ & .58 & .43 & Yes \\
Yttrium & $\mathrm{Y}+3$ & .89 & .66 & Yes \\
Zirconium & $\mathrm{Y}+4$ & .72 & .53 & Yes \\
Antimony & $\mathrm{Sb}+3$ & .77 & .57 & No \\
Cobalt & $\mathrm{Co}+2$ & .73 & .54 & Yes \\
Bismuth & $\mathrm{Bi}+3$ & 1.02 & .75 & No \\
\hline
\end{tabular}

only two of the factors are much less common and are unevenly spread throughout the samples. Cobalt occurs in only two samples, whereas antimony occurs in the rutile from all localities except the east-central Front Range. Bismuth satisfies only the valence factor.

\section{ORIGIN OF METAMORPHIC ROCKS}

We believe that the thick section of metamorphic rocks in the east-central Front Range was originally an assemblage of interlayered shales and graywackes, and local carbonate layers, associated with abundant mafic and felsic volcanic rocks which probably accumulated near their source. Although the origin of the thin lenses and layers of rutile-bearing gneiss is debatable, we believe that most likely they were originally the products of intense subaerial weathering that occurred during the accumulation of the thick succession of sedimentary and volcanic rocks.

\section{MAJOR LITHOLOGIC GROUPS}

The numerous varieties of metamorphic rock in the five principal map units shown in figure 2 comprise three major lithologic groups: biotite gneiss (units A and B), hornblende gneiss and amphibolite (units C and D), and feldspar-rich gneiss (units $\mathrm{C}$ and $\mathrm{E}$ ).

Biotite gneisses and schists in the Front Range were considered to be metamorphosed shaly sediments (Ball, in Spurr, Garrey, and Ball, 1908, p. 44) and subsequent authors have reached the same conclusions. Features that correspond to many present-day successions of sedimentary rock are the wide areal extent of these rocks, the lithologic variation across layers, close interlayering, the apparently conformable contacts, and the composition. Relict sedimentary features are present in some areas, for conglomeratic lenses were noted in mica schist (a lithologic unit traceable laterally to biotite gneiss of this report) in the Ralston Buttes quadrangle (Sheridan, Maxwell, and Albee, 1967, p. 10), and conglomeratic quartzite is interlayered with quartzite and schist in the Coal Creek area (Wells and others, 1964 , p. 7-8). In accordance with all these investigators, we interpret the biotite gneiss of the report area as metasedimentary. The sillimanitic biotite-quartz gneiss was an alumina-rich shale and the intimately interlayered biotite-quartz-plagioclase gneiss was a sandy shale or graywacke. The sillimanitic biotite gneiss containing cordierite- and garnet-bearing layers was an alumina-rich shale having some layers relatively rich in magnesium and iron. Gable and Sims $(1969$, p. 57-59) have also 
ascribed a metasedimentary origin to similar cordierite-bearing rocks in the Front Range.

Hornblende gneiss and amphibolite very likely are metamorphosed intermediate to basic tuffs and flows, and the commonly associated calc-silicate gneiss and impure marble were once sedimentary rocks ranging from calcareous shale to argillaceous limestone. Quartz gneiss, commonly containing magnetite and garnet, is a metamorphic rock equivalent to one type of iron formation.

The feldspar-rich gneisses are thought to have been felsic volcanics. Hedge $(1969$, p. $12,120-123)$ noted that their chemical composition favors an origin as acid volcanic rocks similar to some found in island arc association with basalts. Some authors (Moench and others, 1962, p. 38; Sheridan, Maxwell, and Albee, 1967 , p. 23) have postulated a metasedimentary origin. Sedimentary features and a rock of volcanic composition are not necessarily incompatible; parts of the feldspar-rich gneiss are probably metavolcanics, but other parts were formed by metamorphism of sedimentary tuffs and volcaniclastic rocks.

\section{RUTILE-BEARING GNEISS}

We believe that the light-colored rutile-bearing gneisses of the east-central Front Range originated by intense weathering of intermediate to basic tuffs and flows. This resulted in thin layers of bentonitic clays enriched in titania (leucoxene), alumina (clay), and silica (clay and quartz). These weathering products were reworked by surface waters, and fluorine, emanating from volcanic sources, was adsorbed locally. Clays produced by weathering are commonly low in $\mathrm{Ca}$ and high in A1 and Ti (Rankama and Sahama, 1950, p. 209, 563). Rankama and Sahama (1950, p. 764) stated that fluorine is strongly adsorbed in soils, bentonite, and bottom muds and that fluorine is added to the "exogenic cycle by volcanic processes." Serdyuchenko (1968) believes that many schists and gneisses containing sillimanite, kyanite, or corundum in numerous occurrences around the earth are metamorphosed kaolinite-bauxite weathering crusts. Dunn (1929, p. 248) thought that some of the kyanite-quartz rock in India was originally a surface decomposition of basalt to bauxitic clay. Espenshade and Potter (1960, p. 24-25) concluded that kyanite quartzite in the Farmville district, Virginia, and kyanite quartzite and sillimanite quartzite in the Kings Mountain district, North Carolina-South Carolina, originated from sediments composed of quartz sand containing clay or bauxite.

In the east-central Front Range the intergrading and interlensing of several varieties of rutile-bearing gneiss and their variability in rutile content, from trace amounts to over 5 percent, are best explained by reworking of the original weathered materials. We believe that fluorine from volcanic emanations or from fluorine-rich volcanic rocks was introduced locally into these weathered materials during or shortly after reworking.

In a preliminary report (Sheridan, Taylor, and Marsh, 1968, p. 6), we postulated that rutile-bearing sillimanitic topaz-quartz gneiss was formed by the action of fluorine metasomatism on a gneissic progenitor, such as a sillimanitic quartz-rich gneiss. Such metasomatism seemed necessary to explain the high fluorine content of the gneiss and to account for textural relations indicating that topaz, prismatic sillimanite, and rutile formed at the expense of a previously formed regional metamorphic suite (see figs. 5, 6, and 7 of this report). However, as R. H. Moench (oral commun., 1973) observed, the textural relations do not demand a separate later metamorphic event, because the principal regional metamorphism may have continued long enough after the two early stages of folding to cause the observed textural features. The relations suggest redistribution of primary amounts of fluorine within the affected layers during regional metamorphism, not a metasomatic event related to some later plutonic episode.

\section{OTHER LOCALITIES OF ROCK TYPES SIMILAR TO THOSE IN THE EAST-CENTRAL FRONT RANGE}

Many terranes in the United States and throughout the world contain rock types similar to the Evergreen occurrence. Rutile is reported from many of these occurrences and, although they are low-grade deposits (1-4 percent rutile content), they form a potential resource. The rocks are reported as metasediments, metavolcanics, or metamorphosed weathering crusts, the metamorphism being regional or contact. Although the age of the metamorphosed deposits ranges from Precambrian to Mesozoic, most of reported deposits are in Precambrian rocks. The mineralogy of these rocks is remarkably similar chiefly quartz, aluminum silicate (andalusite, kyanite, and sillimanite) and a variety of accessory minerals. Rutile is present as disseminated fine grains and as scattered larger crystals. Topaz is common and is locally abundant, as in localities described in this report. Phosphate minerals such as apatite, monazite, lazulite, and wagnerite are commonly found. Other accessory minerals found but not universally present are pyrophyllite, ilmenite, magnetite, tourmaline, pyrite, chrome-bearing mica, and zircon. Pegmatites are common in these areas but are younger and do not 
display the distinctive mineralogy of the rutilebearing units. Several of the known occurrences of rutile-bearing rocks are described below.

\section{FARMVILLE DISTRICT, VIRGINIA}

In the Farmville district of central Virginia (Espenshade and Potter, 1960, p. 34-53), layers of rutile-bearing kyanite quartzite in Precambrian rocks occur in a northeast-trending belt about $8 \mathrm{~km}$ wide and $50 \mathrm{~km}$ long. Individual layers range in thickness from a few metres to as much as several hundred metres where repeated by folding. A percent or less rutile is disseminated in the kyanite quartzite as small grains 1 $\mathrm{mm}$ across or smaller. As much as 1 percent of topaz is present locally. Principal associated rock types are hornblende gneiss and biotite gneiss, both containing small amounts of rutile. The chemical nature of these units indicates that they probably were originally graywackes and clay-bearing sandstones interspersed with basaltic or andesitic lava flows. The Farmville district accounts for 50 percent of the known kyanite resources in the southeast United States and, at 0.5 to 1 percent rutile, represents a potential titanium resource.

\section{KINGS MOUNTAIN DISTRICT, NORTH CAROLINA-SOUTH CAROLINA}

In the Kings Mountain district located on the border between North Carolina and South Carolina about 40 km west of Charlotte, N.C. (Espenshade and Potter, 1960 , p. 64-94), rutile occurs as a common accessory in kyanite quartzite and sillimanite quartzite. These units form the upper part of a complexly folded series of schists and gneisses which are dominantly biotite schist and gneiss and hornblende gneiss. These schists and gneisses have been derived principally from volcanic rocks. In the kyanite quartzite the rutile is evenly disseminated as small grains and crystals. No topaz has been reported from this unit but lazulite and tourmaline are rare accessories. The kyanite quartzite layers range in thickness from 6 to $10 \mathrm{~m}$ but appear thicker where repeated by folding.

Rutile is an abundant accessory in the sillimanite quartzite. This unit ranges in thickness from 3 to $9 \mathrm{~m}$ and where undeformed extends along strike as much as $900 \mathrm{~m}$. Topaz is a rare accessory and lazulite is locally abundant. The sillimanite quartzite may represent a later more intense metamorphism of kyanite quartzite. Both units are sedimentary in origin; probably they were clayey sandstones. The Crowders Mountain-Henry Knob area and the Reese Mountain-Clubb Mountain area are the most important in the district and they account for 40 percent of the known kyanite resources in the southeast United States and represent a potential rutile resource.

\section{GRAVES MOUNTAIN, GEORGIA}

Some of the finest rutile specimens in the world come from northeast Georgia at Graves Mountain (Hurst, 1959). The rutile occurs in sericite-kyanitequartz rock and is most abundant in the coarse kyanite-quartz facies cropping out along the top of the mountain. The rutile occurs as small individual disseminated grains and occasional larger crystals and constitutes 0.5 to 1 percent of the rock. Topaz has not been reported from the kyanite-quartz rock, but pyrophyllite and lazulite are common accessories. Some zones contain as much as $\mathbf{1 5}$ percent lazulite. The kyanite-quartz rock crops out in large lenticular bodies as much as $120 \mathrm{~m}$ wide and $550 \mathrm{~m}$ long and is associated with quartz sericite schist and quartz conglomerate. The Graves Mountain area is underlain by a thick sequence of metamorphosed volcanic and sedimentary rocks. The kyanite quartz rock was probably volcanic in origin, possibly a tuff and it belongs to the Little River Series of Crickmay (1952) which may be of Paleozoic age. The unit was folded and regionally metamorphosed to quartz-sericite schists early in its history. A period of fracturing followed the metamorphism and kyanite, lazulite, and rutile were deposited. A late-stage period of cross fractures developed with attendant deposition of pyrophyllite. Most of the rutile is found in a zone $30 \mathrm{~m}$ wide and $150 \mathrm{~m}$ long and represents a small but definable resource.

\section{WHITE MOUNTAIN, CALIFORNIA}

A commercial deposit of andalusite in Precambrian rocks of the Inyo Range near White Mountain, Calif., contains rutile (Kerr, 1932). Rutile also occurs in the surrounding quartz-sericite schist and quartz-micatourmaline schist. These units are thought to be a series of trachytic flows with an interlayering of some highly aluminous material (volcanic or sedimentary). All the metamorphic units were formed by contact metamorphisms by a quartz monzonite porphyry intrusive. A second stage of hydrothermal metamorphism acted on the area during the late stages of the intrusive producing the late mineralization of pyrophyllite and sericite and altering the quartz-sericite schist in many places to diasporequartz-pyrophyllite rock. The main andalusite deposit contains large zones of topaz-quartz, pyrite-quartzandalusite, and trolleite-scorzalite-augelite rock (Gross and Parwel, 1968). Rutile is disseminated throughout the andalusite body as well as the surrounding altered schists in small grains $(0.1$ to 3 
$\mathrm{mm}$ ) and scattered larger crystals and is most abundant in the diaspore-quartz-pyrophyllite rocks. A chemical analysis of rutile from this rock (Gross and Parwel, 1969, p. 495) shows that it is relatively pure containing minor iron and vanadium and trace amounts of tin, chrome, and antimony. Niobium was not detected in the sample. These trace elements were probably included in the rutile from a magmatic source. The scarcity of titanium minerals in the unaltered surrounding schists suggest that the source of rutile mineralization was probably the quartz monzonite porphyry. Deposition of rutile occurred after topaz and andalusite and probably continued throughout both stages of metamorphism. The quantity of rutile present is difficult to estimate, inasmuch as no percentages or tonnages have been given, but rutile is present throughout the metamorphosed area, which covers approximately 2.5 $\mathrm{km}^{2}$ of relatively high-relief terrane.

\section{YUMA COUNTY, ARIZONA}

A rutile-bearing kyanite quartzite on the west side of the Dome Rock Mountains in the NE $1 / 4$ of sec. 34, $\mathrm{T}$. 4 N., R. 21 W., in extreme western Yuma County, Ariz., was visited by Marsh in January 1970. The rutile occurs as small disseminated grains in kyanite quartzite and some larger crystals in small localized quartz veins. The rutile-bearing kyanite quartzite may be divided into two zones, a northerly belt of magnetite-rich quartzite and a southerly belt of rutile-bearing kyanite quartzite. These belts are not well defined and appear to grade one into the other. The rutile zone is approximately $900 \mathrm{~m}$ long and 150 to $300 \mathrm{~m}$ wide, strikes east, and has a northerly dip of about $60^{\circ}$. The rutile zone thickens somewhat to the east. The rutile occurs in clots of small grains. These clots have a roughly rectangular bladed shape and could possibly be relics from some former crystal, perhaps ilmenite. Lazulite is locally abundant and topaz and wagnerite are present. The texture of the rutile-bearing kyanite quartzite is porous and appears leached. The area is mapped by Wilson (1960) as Mesozoic schists, but similar rocks in the adjacent Quartzsite quadrangle have been mapped (Miller, 1968) as Precambrian. Rocks in the area apparently were contact metamorphosed by a quartz monzonite probably of Mesozoic age (Wilson, 1960) adjacent to the rutile-bearing kyanite quartzite. Several samples were collected from the rutile-bearing kyanite quartzite, and four spectrographic analyses of rutile separated from these samples are listed in table 2. Estimates of the amount of rutile in the deposit have not been made, but the outcrop area is sufficiently large to make the area a potential resource.

\section{SANTA CRUZ COUNTY, ARIZONA}

Rutile-bearing quartzite occurs in a contact metamorphosed zone of Triassic volcanics (dacitic and latitic flows) and sedimentary rocks (conglomerates, sandstones, and quartzites) (Drewes, 1971) in the Santa Rita Mountains on the east side of Madera Canyon in the NW ${ }^{1 / 4}$ sec. 1 , T. 20 S., R. 14 E., in northern Santa Cruz County, Ariz. Three samples of quartzite from this locality collected by $\mathrm{Ed}$ Montgomery of Duval Corporation show that andalusite is the common aluminum-silicate mineral and topaz, lazulite, and rutile are accessory. One sample contained as much as 10 percent topaz, suggesting fluorine metasomatism of the quartzite. A large area of Cretaceous granodiorite immediately adjacent to the area was probably responsible for the contact metamorphism. Spectrographic analyses of rutile separates from the three samples are listed in table 2. No accurate estimates of the amount of rutile in this area can be made at present, but the area of contact metamorphism is about $3 \mathrm{~km}$ long and $1 \mathrm{~km}$ wide.

\section{OTHER UNITED STATES OCCURRENCES}

Rutile-bearing gneiss has been reported in several other areas, an indication that primary rutile is more widely distributed in these types of metamorphic rocks than previously recognized.

Fine-grained and locally abundant rutile has been reported in an andalusite, kyanite quartzite of Precambrian age at Kiawa Mountain, N.Mex. (Heinrich and Corey, 1959).

A kyanite mine on the western slope of the Cargo Muchacho Mountains, Imperial County, Calif., is reported to contain euhedral crystals of red rutile (Pemberton and Bideaux, 1968). The deposit occurs in metamorphosed quartz and arkosic sandstone of pre-Mesozoic, possibly Precambrian age. Mesozoic granitoid rocks metamorphosed the sediments. Local hydrothermal action followed intrustion (Henshaw, 1942).

\section{WORLD OCCURRENCES}

The occurrence of rutile-bearing aluminum silicate rocks in other parts of the world is difficult to document. As with the United States occurrences, this rock type is noted in detailed descriptions of aluminum-silicate deposits, with rutile being mentioned as a minor part of the mineral assemblage. A few examples of this type of occurrence are briefly described here.

Australia is the world's largest producer of rutile, and most of it comes from beach placers on the east coast. These deposits have developed through two 
stages of weathering and concentration; detritus from the Precambrian shield rocks were reconsolidated as Mesozoic rocks and then were reworked into the beach placers being mined today. This reworking of sediments served to concentrate the heavy minerals into simpler mineral assemblages because of weathering and removal of less-stable minerals, resulting in minable placer deposits consisting mainly of rutile and zircon. The probable source for the rutile was the crystalline rocks of the interior where rutile occurs in pegmatitic veins and crystalline schists of Precambrian age (Whitworth, 1956, p. 34). Probable commercial amounts of rutile occur in the pegmatites of the Avon district in Western Australia and at Myponga, Parra, and Radium Hill in South Australia. Rutile in the crystalline schists occurs mainly in South Australia in Blumberg, Yankalilla, and Williamstown. The rutile occurs disseminated and along bedding planes in biotite and sillimanite schists. In several of these occurrences rutile is a byproduct or impurity in the mining of aluminous refractory material. As much as 4 percent rutile occurs in a chlorite-corundum rock from Mount Painter, South Australia (Oliver and Jones, 1965).

The Precambrian shield area of northern India contains numerous occurrences of biotite and sillimanite schists that contain disseminated finegrained rutile or small clots of rutile along bedding planes (Dunn, 1929). No report is made of the grade of rutile, but its occurrence is noted at many localities and it appears to be common in some. Accessory minerals are topaz, tourmaline, green micas, corundum, and magnetite. These rutile-bearing rocks are thought to be metavolcanic or metasedimentaryprobably basic lavas or bauxitic clays-in origin (Dunn, 1929, p. 243-252).

In Sweden rutile occurs in three areas of Precambrian metamorphic quartzite (Geijer, 1964). The largest is at Haallsjöberget in southwest Sweden where rutile occurs as streaks and veinlets in kyanitebearing quartzite. Lazulite, iron-rich wagnerite, and pyrophyllite are also present. No size or grade figures are given, but rutile is reported as abundant in some of the kyanite concentrations. A similar but smaller deposit occurs at Dicksberget, $60 \mathrm{~km}$ south of Haallsjöberget. Here, quartzite with $15-25$ percent kyanite has accessory rutile, ilmenite, lazulite, and pyrite. The third deposit is at Västanaa near the southern Baltic coast where Precambrian quartzite contains commercially worked hematite deposits. Here, quartzite is overlain by alumina-rich mica schist containing kyanite, andalusite, and sparse sillimanite. Rutile is widespread and amounts to about 1 percent of the rock. Other accessory minerals include lazulite, zircon, and pyrophyllite, These occurrences are thought to be high-temperature replacement deposits of originally high-alumina and silica rocks.

Serdyuchenko (1968), described several areas where rutile occurs with aluminum-silicate rocks. In south Norway at Arendal rutile occurs in amounts as great as 1 percent in corundum-bearing gneisses containing lazulite and sillimanite. In the Orange River Basin in Namaqualand, South-West Africa, rutile occurs as an accessory (1 percent) in sillimanite and sillimanite-corundum beds in metamorphic rocks.

\section{ECONOMIC POTENTIAL}

For reasons cited in the introduction, rutile deposits of the Evergreen area may never be mined. Data reported below illustrate resources that can be expected if continued search elsewhere discloses deposits of similar size and mineralogy.

The sillimanitic topaz-quartz gneiss constitutes the most important type of rutile-bearing rock in the Evergreen area. The following computations are made from the layers of this rock from sample locality $A$ to sample locality D (fig. 2), a strike length of $2,100 \mathrm{~m}$. The unit is exposed to a depth of $73 \mathrm{~m}$; the thickness ranges from 3 to $21 \mathrm{~m}$ and averages $12 \mathrm{~m}$. Chemical analyses of four samples (1 to 4 , table 2 ) were used to calculate average mineralogic grade: rutile, 2.1 percent; topaz, 28.5 percent; sillimanite, 12.3 percent. The indicated resources, using a rock density of 3.00 , are 5.5 million metric tons of sillimanitic topaz-quartz gneiss. These contain 115,000 metric tons of rutile, $1,600,000$ metric tons of topaz, 670,000 metric tons of sillimanite, and 3,115,000 metric tons of quartz. Each additional $30 \mathrm{~m}$ of depth contains the inferred resources: 47,000 metric tons of rutile, 646,000 metric tons of topaz, and 280,000 metric tons of sillimanite. Although the rutile is fine-grained (commonly $0.5 \mathrm{~mm}$ or less in size), laboratory tests show that much of it is freed in the crushing stage and much of the remainder is freed by grinding to $175 \mu \mathrm{m}$.

Extending west-northwestward from the west end of the deposit described above (sample locality A, fig. 2 ) is the $\mathrm{Z}$-shaped trace of other rutile-bearing gneisses that contain 0.5 to 2.5 percent rutile. As measured along the trace, these are about $11 \mathrm{~km}$ in length and range in thickness from $30 \mathrm{~cm}$ to $9 \mathrm{~m}$. In the area to the southeast are several lenses of sillimanitic topaz-quartz gneiss that range in length from 60 to 800 $m$ and in thickness from $15 \mathrm{~cm}$ to $8 \mathrm{~m}$; the rutile content ranges from 0.5 to 3 percent. Other rutile-bearing layers typically contain less than 1 percent rutile and are not considered to be a resource. 


\section{REFERENCES CITED}

Bryant, Bruce, Miller, Rd. D., and Scott, G. R., 1973, Geologic map of the Indian Hills quadrangle, Jefferson County, Colorado: U.S. Geol. Survey Geol. Quad. Map GQ-1073 7 p. [1974].

Crickmay, G. W., 1952, Geology of the crystalline rocks of Georgia: Georgia Geol. Survey Bull. no. 58, 54 p.

Drewes, Harold, 1971, Geologic map of the Mount Wrightson quadrangle, southeast of Tucson, Santa Cruz and Pima Counties, Arizona: U.S. Geol. Survey Misc. Geol. Inv. Map I-614.

Dunn, J. A., 1929, The aluminous refractory materials: kyanite, sillimanite, and corundum in northern India: India Geol. Survey, Mem. 52, pt. 2, p. 145-274.

Espenshade, G. H., and Potter, D. B., 1960, Kyanite, sillimanite, and andalusite deposits of the southeastern States: U.S. Geol. Survey Prof. Paper 336, 121 p.

Fleischer, Michael, and Robinson, W. 0., 1963, Some problems of the geochemistry of fluorine, in Studies in analytical geochemistry: Royal Soc. Canada Spec. Pub. 6, p. 58-75.

Gable, D. J., 1968, Geology of the crystalline rocks in the western part of the Morrison quadrangle, Jefferson County, Colorado: U.S. Geol. Survey Bull. 1251-E, p. E1-E45.

Gable, D. J., and Sims, P. K., 1969, Geology and regional metamorphism of some high-grade cordierite gneisses, Front Range, Colorado: Geol. Soc. America Spec. Paper 128, 87 p.

Geijer, Per, 1964,Genetic relationships of the paragenesis Al2Si05lazulite-rutile: Arkiv Mineralogi och Geologi, v. 3, no.24, p. 423-466.

Gross, E. B., and Parwel, A., 1969, Rutile mineralization at the White Mountain andalusite deposits, California: Arkiv Mineralogi och Geologi, v. 4, no. 6, paper 29 p. 493-497.

Hedge, C. E., 1969, A petrogenetic and geochronologic study of migmatites and pegmatites in the central Front Range: Colorado School Mines, unpub. PhD. thesis, $158 \mathrm{p}$.

Heinrich, E. W., and Corey, A. F., 1959, Manganian andalusite from Kiawa Mountain, Rio Arriba County, New Mexico: Am. Mineralogist, v. 44, p. 1261-1271.

Henshaw, P. C., 1942, Geology and mineral deposits of the Cargo Muchacho Mountains, Imperial County, California: California Jour. Mines and Geology, v. 38, no. 2, p. 147-196.

Hurst, V. J., 1959, The geology and mineralogy of Graves Mountain, Georgia: Georgia Geol. Survey Bull 68, 33 p.

Kerr, P. F., 1932, The occurrence of andalusite and related minerals at White Mountain, California: Econ. Geology, v. 27, no. 7, p. 614-643.

Krauskopf, K. B., 1967, Introduction to geochemistry: New York, McGraw-Hill Book Co., 721 p.

Lovering, T. S., and Goddard, E. N., 1950, Geology and ore deposits of the Front Range, Colorado: U.S. Geol. Survey Prof. Paper 223, 319 p.

Miller, F. K., 1968, Geology of the Quartzsite quadrangle, Arizona: U.S. Geol. Survey Open-file rept. (Denver OF Temp. 783).

Moench, R. H., 1964, Geology of Precambrian rocks, Idaho Springs district, Colordo: U.S. Geol. Survey Bull. 1182-A, p. A1-A70.

Moench, R. H., Harrison, J. E., and Sims, P. K., 1962, Precambrian folding in the Idaho Springs-Central City area, Front Range, Colo.: Geol. Soc. America Bull., v. 73, no. 1, p. 35-58.
Myers, A. T., Havens, R. G., and Dunton, P. J., 1961, A spectrochemical method for the semiquantitative analysis of rocks, minerals, and ores: U.S. Geol. Survey Bull. 1084-I, p. 207-229.

National Materials Advisory Board, 1972, Processes for rutile substitutes; appendix B, National stockpile purchase specifications, P-49-R5, November 1, 1967: Washington, D.C., National Materials Advisory Board NMAB-293.

Oliver, R. L., and Jones, J. B., 1965, A chlorite-corundum rock from Mount Painter, South Australia: Mineralogy Mag., v. 35, no. 269 , p. $140-145$.

Pauling, Linus, 1929, The principles determinging the structure of complex ionic crystals: Jour. Am. Chem. Soc. v. 51, p. 1010-1026.

Pemberton, H. E., and Bideaux, R. A., 1968, An occurrence of svanbergite in California: Mineral Explorer, v. 3, no. 1, p. 11.

Rankama, Kalervo, and Sahama, Th. G., 1950, Geochemistry: Chicago, Chicago Univ. Press, 912 p.

Serdyuchenko, D. P., 1968, Metamorphosed weathering crusts of the Precambrian, their metallogenic and petrographic features: Internat. Geol. Cong., 23d, Prague, Czechoslovakia, 1968, sec. 4 Proc., 37-42.

Shannon, R. D., and Prewitt, C. T., 1969, Effective ionic radii in oxides and fluorides: Acta Cryst., sect. B, v. 25, p. 925-946.

Sheridan, D. M., Marsh, S. P., Mrose, M. E., and Taylor, R. B., 1971, Wagnerite from Santa Fe Mountain, Colorado - a new occurrence [abs.]: Canadian Mineralogist, v. 10, pt. 5, p. 919.

Sheridan, D. M., Maxwell, C. H., and Albee, A. L., 1967, Geology and uranium deposits of the Ralston Buttes district, Jefferson county, Colorado, with sections on Paleozoic and younger sedimentary rocks, by Richard Van Horn: U.S. Geol. Survey Prof. Paper 520, $121 \mathrm{p}$.

Sheridan, D. M., Reed, J. C., Jr., and Bryant, Bruce, 1972, Geologic map of the Evergreen quadrangle, Jefferson County, Colorado: U.S. Geol. Survey Misc. Geol. Inv. Map I-786-A (1973).

Sheridan, D. M., Taylor, R. B., and Marsh, S. P., 1968, Rutile and topaz in Precambrian gneiss, Jefferson and Clear Creek Counties, Colorado: U.S. Geol. Survey Circ. 567, 7 p.

Sims, P. K., and Gable, D. J., 1967, Petrology and structure of Precambrian rocks, Central City quadrangle, Colorado: U.S. Geol. Survey Prof. Paper 554-E, p. E1-E56.

Spurr, J. E., Garrey, G. H., and Ball, S. H., 1908, Economic geology of the Georgetown quadrangle (together with the Empire district), Colorado: U.S. Geol. Survey Prof. Paper $63,422 \mathrm{p}$.

Tweto, Ogden, and Sims, P. K., 1963, Precambrian ancestry of the Colorado mineral belt: Geol. Soc. America Bull., v. 74, no. 8, p. 991-1014.

Wells, J. D., Sheridan, D. M., and Albee, A. L., 1964, Relationship of Precambrian quartzite-schist sequence along Coal Creek to Idaho Springs Formation, Front Range, Colorado: U.S. Geol. Survey Prof. Paper 454-0, 25 p.

Whitworth, H. F., 1956, The zircon-rutile deposits on the beaches of the east coast of Australia with special reference to their mode of occurrence and the origin of the minerals, in Geological survey of New South Wales: New South Wales Dept. Mines Tech. Rept., v. 4, p. 7-60.

Wilson, E. D., 1960, Geologic map of Yuma County, Arizona: Tucson, Arizona Bur. Mines. 

